\title{
Transcriptome Profile Analysis Reveals an Estrogen Induced LncRNA Associated with Lipid Metabolism and Carcass Traits in Chickens (Gallus Gallus)
}

\author{
Hong Li $i^{a, b, c}$ Zhenzhen Gu ${ }^{d}$ Liyu Yang ${ }^{a}$ Yadong Tian ${ }^{a, b, c} \quad$ Xiangtao Kanga,b,c \\ Xiaojun Liu ${ }^{a, b, c}$
}

aCollege of Animal Science and Veterinary Medicine, Henan Agricultural University, Zhengzhou, ${ }^{\circ}$ Henan Innovative Engineering Research Center of Poultry Germplasm Resource, Zhengzhou, International Joint Research Laboratory for Poultry Breeding of Henan, Zhengzhou, 'Key Laboratory of Genetics, Breeding \& Reproduction of Grass-Feeding Livestock, Ministry of Agriculture, Xinjiang Academy of Animal Science, Urumqi, China

\section{Key Words}

Chicken $\bullet$ LncRNA $\bullet$ Lipid metabolism $・$ Liver $・$ Estrogen $\bullet$ RNA-seq

\begin{abstract}
Background/Aims: Accumulating evidences have demonstrated that long noncoding RNAs (IncRNA) play important roles in hepatic lipid metabolism in mammals. However, no systematic screening of the potential IncRNAs in the livers of laying hens has been performed, and few studies have been reported concerning the effects of the IncRNAs on lipid metabolism in the livers of chickens during egg-laying period. The purpose of this study was to compare the difference in IncRNA expression in the livers of pre-laying and peak-laying hens at the age of 20 and 30 weeks old by transcriptome sequencing and to investigate the interaction networks among IncRNAs, mRNAs and miRNAs. Moreover, the regulatory mechanism and biological function of IncLTR, a significantly differentially expressed IncRNA in the liver between pre- and peak-laying hens, was explored in vitro and in vivo. Methods: Bioinformatics analyses were conducted to identify the differentially expressed (DE) IncRNAs between the two groups of hens. The target genes of the DE IncRNA were predicated for further functional enrichment. An integrated analysis was performed among the DE IncRNA datasets, DE mRNAs and DE miRNA datasets obtained from the same samples to predict the interaction relationship. In addition, in vivo and in vitro trials were carried out to determine the expression regulation of IncLTR, and polymorphism association analysis was conducted to detect the biological role of IncLTR. Results: A total of $124 \mathrm{DE}$ IncRNAs with a $P$-value $\leq 0.05$ were identified. Among them, 44 IncRNAs including 30 known and 14 novel IncRNAs were significant differentially expressed $(\mathrm{SDE})$ with FDR $\leq 0.05$. Thirty-two IncRNAs were upregulated and 12 were downregulated in




\section{Cellular Physiology Cell Physiol Biochem 2018;50:1638-1658 and Biochemistry Published online:2 November $2018 \begin{aligned} & \text { (c) } 2018 \text { The Author(s). Published by S. Karger AG, Basel } \\ & \text { www.karger.com/cpb }\end{aligned}$ \\ Li et al.: Chicken LncRNA and Lipid Metabolism}

peak-laying group compared with pre-laying group. The functional enrichment results revealed that target genes of some IncRNAs are involved in the lipid metabolism process. Integrated analysis suggested that some of the genes involved in lipid metabolism might be regulated by both the IncRNA and the miRNA. In addition, an upregulated IncRNA, designated IncLTR, was demonstrated to be induced by estrogen via ER $\beta$ signaling. The $c 242$. G>A SNP in IncLTR was significantly associated with chicken carcass weight, evisceration weight, semi-evisceration weight, head weight, double-wing weight, claw weight traits, and blood biochemical index, especially for the blood triglyceride content. Conclusion: A series of IncRNAs associated with lipid metabolism in the livers of chickens were identified by transcriptome sequencing and functional analysis, providing a valuable data resource for further studies on chicken hepatic metabolism activities. LncLTR was regulated by estrogen via ER $\beta$ signaling and associated with chicken carcass trait and blood triglyceride content.

(C) 2018 The Author(s)

Published by S. Karger AG, Basel

\section{Introduction}

Long noncoding RNAs (lncRNAs) are a class of long nonprotein-coding RNA exceeding 200 nucleotides in length. They are poorly conserved and modulate gene expression through a variety of mechanisms, which are not yet clearly understood [1,2]. Although the molecular regulatory mechanisms of the majority of lncRNAs are largely unclear, it is known that IncRNAs control every level of gene expression programs [3] and act by activating or repressing the transcriptional activity of other genes either in cis or in trans, or by modifying their transcript abundance [4]. In addition, lncRNAs have been reported to be involved in posttranscriptional gene regulation by controlling some biological processes, such as RNA maturation, transport, protein synthesis, and transcriptional gene silencing through modification of the chromatin structure $[1,2,5]$.

Many studies have suggested that IncRNAs serve as important controllers during adipogenesis [6], adipocyte differentiation [7], liver development [8], and hepatic lipid metabolism [9]. Some lncRNAs play an important role in the cholesterol metabolism in HepG2 cells [10]. LincRNA-DYNLRB2-2 is essential for the regulation of cholesterol homeostasis [11]. A liver-enriched IncRNA-IncLSTR regulates the TDP-43/FXR/apoC2-dependent pathway to maintain systemic lipid homeostasis in mice [12]. With the ability to promote lipogenesis, lncRNA-HULC can stimulate the accumulation of intracellular triglycerides and cholesterol both in vitro and in vivo [13].

Aberrant expression of IncRNAs can cause miRNA disorders due to the length of IncRNAs, and they can control the miRNA abundance through binding and sequestration of the miRNA, functioning as so-called "miRNA sponges" [14, 15]. A study has demonstrated that a highly upregulated lncRNA may serve as an endogenous sponge, which can downregulate a series of miRNA activities in liver cancer [16]. As is well-known, miRNAs exert their functions by either direct degradation or translational repression through interacting with complementary sequence motifs in the 3' untranslated regions of target mRNAs for a specific gene [17]. Both lncRNAs and miRNAs are endogenously expressed regulators of gene expression [18]. Given the complex interaction among lncRNAs, miRNAs and mRNAs, it is necessary to integrate these datasets to further reveal the regulatory mechanisms among lncRNAs-mRNAs-miRNAs [19].

Although extensive profiling of the IncRNA transcriptome in the chicken liver has been reported [20], the physiological significance of IncRNAs in the hepatic lipid metabolism of chicken remains poorly understood. The liver is the most critical site for lipid synthesis in chicken, where more than $90 \%$ of total fatty acid de novo synthesis occurs [21]. To satisfy the physiological adaptation required for laying lipid-rich eggs in laying hens [22], large amounts of egg-yolk precursors consist of proteins and lipids, including triacylglycerols, cholesteryl esters, cholesterol esters, and free fatty acids synthesized in the liver, which are transferred to the ovarian follicles [23]. This process is highly dependent on the induction of estrogen [22], which suggests that in addition to protein-coding RNAs, the ncRNAs, including lncRNAs,

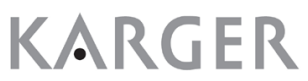




\section{Cellular Physiology Cell Physiol Biochem 2018;50:1638-1658 \begin{tabular}{ll|l} 
and Biochemistry & $\begin{array}{l}\text { DOl: 10.1159/000494785 } \\
\text { Published online: 2 November } 2018\end{array}$ & $\begin{array}{l}\odot \text { 2018 The Author(s). Published by S. Karger AG, Basel } \\
\text { www.karger.com/cpb }\end{array}$ \\
\cline { 2 - 3 }
\end{tabular} \\ Li et al.: Chicken LncRNA and Lipid Metabolism}

involved in lipid metabolism may also be affected by estrogen. Alterations of specific lncRNA levels in chicken liver may be responsible for the changes in physiological or pathological functions of divergent origin. The precise regulatory mechanisms of IncRNAs involved in chicken liver lipid metabolism are largely unknown.

To gain insight into the role of IncRNAs that serve as hepatic lipid metabolism regulatory molecules and to reveal the regulatory relationship among lncRNAs, mRNAs and miRNAs in chicken, we first analyzed the potential target protein-coding genes and miRNAs of IncRNAs, and then performed an integrated analysis. Elucidation of the expression patterns of lncRNAs and their interaction network with miRNAs and putative target genes will broaden understanding of the hepatic lipid metabolism process during egg-laying stage in poultry. Therefore, identifying the expression profiles of lncRNAs in chicken liver may facilitate understanding of the functional roles of lncRNAs during lipid metabolism.

With the completion of a number of genome-wide association studies and transcriptome sequencing analyses, more candidate genes and significant SNPs have been found to affect chicken growth traits $[24,25]$. However, very few studies have addressed other genetic factors controlling chicken growth, such as lncRNA regulation and epigenetic inheritance, and therefore the genetic mechanisms responsible for chicken growth are far from clear. It is generally considered that the regulatory mechanism controlling the expression of lncRNAs is complex (e.g., genetic variation), and lncRNAs can serve as important intermediate controllers in the regulation of downstream molecular and cellular functions. As one of the most common and concerning genetic variants, single-nucleotide polymorphisms (SNPs) are universally present in lncRNAs genes, and they may directly or indirectly lead to changes in lncRNA expression levels through various means and hence participate in various biological processes [26]. Therefore, revealing the SNPs occurred in lncRNAs will uncover their functional mechanisms underlying association specifically mediated by lncRNAs. However, the associations between genetic polymorphisms of IncRNA and chicken economic traits have been less investigated. We found that the expression level of IncRNA-NONGGAT003016.2 (termed "IncRNA estrogen mediated regulator") was 9.6-fold higher in livers of pre-laying hens compared with peak-laying hens. The IncRNA was designated IncLTR (a lncRNA acting as a Liver Triglyceride synthesis Regulator).

In this study, the potential IncRNAs that might associate with hepatic lipid metabolism in egg-laying chickens were identified by analyzing the differential expression profiles of lncRNAs in livers between pre- and peak-laying hens. The interactions among lncRNAs, mRNAs and miRNAs were investigated by network construction. In addition, the regulatory mechanism of IncLTR, a significantly differentially expressed lncRNA in liver between preand peak-laying hens, was explored both in vitro and in vivo, and its biological function was investigated by an association analysis using a F2 resource population.

\section{Materials and Methods}

\section{Bioinformatics analyses}

The transcriptome data of chicken liver (GSE70010, NCBI GEO database) [27], which were obtained using the RNA-seq technique on the Illumina HiSeq 2500 platform (Illumina) with liver tissues of hens at pre- and peak-laying physiological stages with three replicates for each stage, was used to identify chicken liver-enriched IncRNAs. The transcriptome data were re-annotated through an integrated analysis based on the annotation of the NONCODEV5 database (version 2016) and Ensemble database (Ensembl release 88). To identify potentially novel reliable IncRNAs, the known transcripts that appeared in NONCODEV5 or Ensembl were filtered out by the Cuffcompare program of the Cufflinks package to identify putative noncoding transcripts.

According to the various genomic positions of lncRNA types with respect to other genes, the lncRNAs were classified [28]. Cufflinks (version: 2.1.1) [29] was used to analyze the expression levels of known and novel lncRNAs by the number of uniquely mapped fragments per kilobase of exon per million fragments mapped (FPKM). Differential gene expression was determined with a P-value $\leq 0.05$, and significance was 


\section{Cellular Physiology Cell Physiol Biochem 2018;50:1638-1658

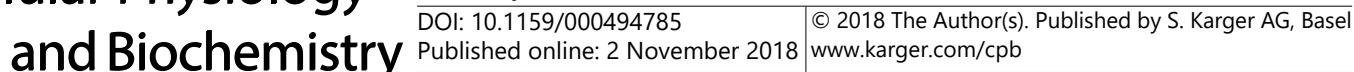

Li et al.: Chicken LncRNA and Lipid Metabolism

determined by normalizing the reads and calculating the $P$-value using Fisher's exact test. The false discovery rate (FDR) was used to determine the threshold of the $P$-value in multiple tests and analyses. LncRNAs with FDR $\leq 0.05$ were identified as significant differentially expressed (SDE) lncRNAs [30].

\section{LncRNA target gene prediction and annotation}

LncRNA plays a role through acting on protein-coding genes via the trans-acting factor and/or cisacting element. The closest coding genes $10 \mathrm{~kb}$ upstream and downstream of lncRNAs screened using the BEDTools v2.25.0 program [31] were considered as the putative cis-acting targets of IncRNA. In addition, IncRNAs can regulate the expression of genes that are located on other chromosomes in a trans acting manner [32], and the genes were considered the putative trans targets of IncRNAs. Then, the putative differentially expressed ( $P$-value $\leq 0.05$ ) (DE) target genes of SDE lncRNAs (including both cis and trans) were identified from the DE gene $(P$-value $\leq 0.05)$ dataset presented in previous transcriptome sequence results [27].

To understand the possible functions of DE IncRNAs, all their cis and trans-acting genes were submitted to KOBAS 3.0 [33] for functional enrichment analysis using the Gene Ontology (GO) dataset and Kyoto Encyclopedia of Genes and Genomes (KEGG) pathway dataset (http://kobas.cbi.pku.edu.cn/index. php). Given the $P$-values in our analysis, only the GO terms and KEGG pathways with $P$-values $\leq 0.05$ were taken into account as statistically significant enrichment [34].

Interactions among IncRNAs, mRNAs and miRNAs

To evaluate the co-expression relationships between SDE IncRNAs and DE mRNAs obtained from the same transcriptome data as reported previously [27], their co-expression networks were constructed based on a correlation coefficient of more than 0.98 and $P$-value $\leq 0.0001$ using Cytoscape (Version 3.3.0) [35]. The effects of miRNAs on IncRNAs have been less frequently reported in a domestic animal model. To fully understand the possible interaction between IncRNAs and miRNAs, the target miRNAs of SDE IncRNAs were predicted by adopting the miRanda software from the liver miRNA differential expression dataset GSE74242, which was sequenced from the same experimental mode. Moreover, based on the predicted target pairs of miRNA-IncRNA and miRNA-mRNA analyzed according to previous work [36], the miRNAs that interacted with both lncRNAs and mRNAs were selected to perform the interaction network using Cytoscape software.

\section{LncLTR protein-coding potential prediction}

The protein-coding potential of the lncLTR sequence was evaluated by two commonly used algorithms, Coding-Non-Coding Index (CNCI) [37] and Coding Potential Calculator (CPC) [29]. For CPC, as a rule, transcripts with a score between -1 and 1 are marked as 'weak noncoding' or 'weak coding', a score more than 1 are classified as "coding", and a score less than - 1 as "noncoding", respectively. For CNCI, the transcripts with scores greater than 0 are classified as coding, while those less than 0 are noncoding. The CNCI score of IncLTR is -0.0364544 , indicating that it is a noncoding RNA. The CPC score of IncLTR is -0.688335 , which was calculated with http://cpc.cbi.pku.edu.cn/programs/cpc.do using default thresholds. Furthermore, the coding potential of IncLTR was also predicted with the functional domain database Pfam, which also indicated the absence of a Pfam domain. LncLTR was scanned to identify putative open reading frames (ORFs) exceeding 150 bp using ATG as the start codon and TAA, TAG, and TGA as stop codons and revealed seven short ORFs, one of which was $375 \mathrm{bp}$ and the others less than $300 \mathrm{bp}$, and below the cutoff for the lncRNAs. We then searched the putative ORFs in protein databases, including the nonredundant GenBank CDS translations+ SwissProt, excluding environmental samples of unknown sources from WGS projects, and we found no matches to any known protein. Finally, we searched these putative ORFs against the Conserved Domain Database (http://www.ncbi.nlm.nih.gov/Structure/bwrpsb/bwrpsb.cgi) and found no matches.

\section{Animals and sample preparation}

To explore the expression pattern and possible biological role of lncLTR, in vivo and in vitro trials were conducted. All the experimental animals used in the research were raised in the same environment with ad libitum food and water in the core breeding farm of Henan Agricultural University. At the age of 10, 15, 20, 30 and 35 weeks old, eight Lushi Green-shelled-egg hens were collected from each group, respectively. The 


\section{Cellular Physiology Cell Physiol Biochem 2018;50:1638-1658 \begin{tabular}{l|l|l} 
and Biochemistry Published online: 2 November 2018 & $\begin{array}{l}\odot 2018 \text { The Author(s). Published by S. Karger AG, Basel } \\
\text { www.karger.com/cpb }\end{array}$ \\
\hline
\end{tabular}}

Li et al.: Chicken LncRNA and Lipid Metabolism

chickens were ethically slaughtered. Liver tissues were collected, snap frozen in liquid nitrogen, and stored at $-80^{\circ} \mathrm{C}$ until use. The animal experiments were carried out according to the protocol approved by the Institutional Animal Care and Use Committee of Henan Agricultural University (Permit Number: 11-0085).

\section{Effect of estrogen on the expression of IncLTR in birds}

Forty healthy Hyline brown hens at the age of 10 weeks old were randomly divided into four groups. Chickens in the three treatment groups were given $17 \beta$-estradiol at $0.5,2$, and $8 \mathrm{mg} / \mathrm{kg}$ body weight dissolved in olive oil, respectively. Chickens that received olive oil only were used as controls. All chickens were ethically slaughtered at 12 hours after treatment. Liver tissues were collected, snap frozen in liquid nitrogen, and stored at $-80^{\circ} \mathrm{C}$ for further analysis.

\section{Cell culture}

Fertilized specific pathogen-free chicken eggs purchased from Beijing Meiliyaweitong Experimental Animal Technology Co. Ltd. (Beijing, China) were incubated at $38^{\circ} \mathrm{C}$ with a relative humidity of $65 \%$. According to previous methods [38,39], hepatocytes of chicken embryo were collected from the livers at embryonic day 18. In brief, livers separated from the chicken embryos were washed with D-Hanks solution (Solarbio, Beijing, China) and digested using collagenase type II (Sigma, USA) at $37^{\circ} \mathrm{C}$ for $30 \mathrm{~min}$. Dispersed cells were filtered through a 200-mesh sieve and a 500-mesh sieve and separated from other cells through noncontinuous density Percoll gradient centrifugation. The cells were then resuspended in Williams' E complete medium (Sigma St Louis, MO, USA) containing 10\% fetal calf serum and $100 \mathrm{U} / \mathrm{mL}$ penicillin and $100 \mathrm{mg} / \mathrm{mL}$ streptomycin. Hepatocytes were seeded in a 6-well plate at a density of $1.0 \times 10^{6}$ cells/well. The cells were incubated in an incubator at $37^{\circ} \mathrm{C}$ under a water-saturated atmosphere containing $95 \%$ air humidity and $5 \% \mathrm{CO}_{2}$.

To evaluate the effect of estrogen on gene expression, cells reaching $80 \%$ confluence were starved for 6 hours with serum-free medium and stimulated with different concentrations of $17 \beta$-estradiol ( $25 \mathrm{nM}, 50$ $\mathrm{nM}$ and $100 \mathrm{nM}$ ). The control group received vehicle alone. The cells were collected 18 hours after treatment and stored at $-80^{\circ} \mathrm{C}$. All experiments were repeated at least three times with triplicates in each assay.

To investigate the subtypes of estrogen receptor mediating the estrogen signaling, the cells reaching $80 \%$ confluence were starved for 6 hours, then treated with $100 \mathrm{nM} 17 \beta$-estradiol alone or combined with $1 \mu \mathrm{M}$ of different estrogen receptor antagonists MPP, or tamoxifen, or ICI 182, 780. The control group received ethanol (solvent for $17 \beta$-estradiol) and DMSO (solvent for the antagonists) at a final concentration of $0.1 \%$ each. The cells were collected after treatment.for $24 \mathrm{~h}$ and stored at $-80^{\circ} \mathrm{C}$ for further analysis. All experiments were repeated at least three times with triplicates in each assay.

\section{SNP detection and association analysis}

To identify SNPs that may naturally occur in IncLTR and investigate the potential biological effect of the SNPs on various traits in chicken, an $\mathrm{F}_{2}$ population of 860 chickens generated from a cross of Gushi chickens (a slow-growing local chicken) and Anka chickens (a fast-growing broiler) as previously described [40, 41] was used for the SNP scanning and association analysis in this experiment. All the chickens were managed under the same environment with free access to feed and water, and they were slaughtered at 12 weeks of age. A total of 860 genomic DNA samples were extracted from serum blood samples of $F_{2}$ individuals using the phenol-chloroform method [42]. Growth traits including body weight and body size were recorded at different stages, and traits including carcass, meat quality and blood biochemistry parameters were carefully measured after slaughter $[43,44]$.

A DNA pool constructed by mixing one hundred DNA samples selected randomly from the F2 individuals with the same working concentration and equal amounts was used as the PCR template. The PCR reaction component contained approximately $50 \mathrm{ng}$ of genomic DNA, $0.5 \mu \mathrm{M}$ each forward and reverse primer, and 5 $\mu \mathrm{L}$ of $2 \times$ Taq MasterMix (Cwbiotech, Beijing). The amplification conditions included an initial denaturation at $94{ }^{\circ} \mathrm{C}$ for $5 \mathrm{~min}$, followed by 35 cycles of $94^{\circ} \mathrm{C}$ for $30 \mathrm{~s}, 55^{\circ} \mathrm{C}$ for $30 \mathrm{~s}$, and $72^{\circ} \mathrm{C}$ for $30 \mathrm{~s}$, with a final extension at $72{ }^{\circ} \mathrm{C}$ for $10 \mathrm{~min}$. The PCR products were sequenced by Shanghai Sangon Bio Co. Ltd. (Shanghai, China) to identify the mutation in IncLTR. The PCR restriction fragment length polymorphism (PCR-RFLP) method was used to analyze the SNP. The relevant restriction enzyme was selected using online software (http://watcut. uwaterloo.ca/template.php). The PCR products were digested in a restriction enzyme mixture overnight at $37^{\circ} \mathrm{C}$. Finally, the digested products were checked by $2.0 \%$ agarose gel electrophoresis and genotyped. The 


\section{Cellular Physiology Cell Physiol Biochem 2018;50:1638-1658 and Biochemistry \begin{tabular}{l|l} 
DOI: 10.1159/000494785 & $\begin{array}{l}\text { (c) } 2018 \text { The Author(s). Published by S. Karger AG, Basel } \\
\text { www.karger.com/cpb }\end{array}$
\end{tabular} \\ Li et al.: Chicken LncRNA and Lipid Metabolism}

different genotypes were further confirmed by PCR product sequencing at Shanghai Sangon Bio Co. Ltd. (Shanghai, China). Nucleotide sequence alignments were performed using DNAMAN software.

Table 1. The primers used for qPCR verification and PCR

\begin{tabular}{ccccc}
\hline Usage & Gene ID & $\begin{array}{c}\text { Forward Primer } \\
\left(5^{-}-3^{\prime}\right)\end{array}$ & $\begin{array}{c}\text { Reward Primer } \\
\left(5^{\prime}-3^{\prime}\right)\end{array}$ & PCR product (bp) \\
\hline qPCR & NONGGAT003016.2 & GGGACAAAGACTCACCCACTG & CATTGGGGGTCTTCTGTGTGA & 109 \\
& NONGGAT003795.2 & ACTATCACTCGCACTACCGC & GTTACCTGACTCAAGGGGGC & 161 \\
& NONGGAT007149.2 & AGTTCATCCTCCCAGTTCCA & CCAGGTAGGTGATGGATCAA & 181 \\
& NONGGAT002911.2 & CCCCATTCTCCTTTCCTTC & GAGAACGGCGAGAGGTGTAG & 250 \\
& NONGGAT004633.2 & GGGATTTATGGAGGTGCTGA & CCATCGGGGTATGTGGAGTA & 203 \\
& TCONS_00077066 & ACCCTGAGCTGGAATAGAGTG & AAGTGCTGCCCCGCTGAGACC & 120 \\
& NONGGAT002034.2 & TGGGATAACAGCACGGACAC & CCAGGAGTGCAAATGATGCG & 111 \\
& $\beta$-actin & CAGCCAGCCATGGATGATGA & ACCAACCATCACACCCTGAT & 118 \\
PCR & NONGGAT003016.2 & AGGGAGCCTTGTTCAGTTGG & AGCAAGGAAATCCACAGCGA & 508 \\
\hline
\end{tabular}

The following two linear mixed-model procedures of SPSS statistical 23.0 were used for association analysis between the genotype and chicken economic traits:

Model I: $\mathrm{Y}_{\mathrm{ijklm}}=\mu+\mathrm{G}_{\mathrm{i}}+\mathrm{S}_{\mathrm{j}}+\mathrm{H}_{\mathrm{k}}+\mathrm{f}_{\mathrm{l}}+\mathrm{e}_{\mathrm{ijklm}}$

Model II: $\mathrm{Y}_{\mathrm{ijklm}}=\mu+\mathrm{G}_{\mathrm{i}}+\mathrm{S}_{\mathrm{j}}+\mathrm{H}_{\mathrm{k}}+\mathrm{f}_{\mathrm{l}}+\mathrm{b}\left(\mathrm{W}_{\mathrm{ijklm}}-\mathrm{W}\right)+\mathrm{e}_{\mathrm{ijklm}}$

where $Y_{i j k l m}$ represents the individual value, $\mu$ the observation mean, $G_{i}$ the fixed effect of genotype ( $i$ = genotypes), $f_{1}$ the random effect of family $(l=7), S_{j}$ fixed effect of sex $(j=f, m), H_{k}$ the fixed effect of hatch $(\mathrm{k}=2)$, and $\mathrm{e}_{\mathrm{ijklm}}$ the random error. $\mathrm{b}$ is the regression coefficient for carcass weight, $\mathrm{W}_{\mathrm{ijklm}}$ the carcass weight of the individual, and $\mathrm{W}$ the average carcass weight. Model I was used to evaluate growth and meat quality traits. Considering the effect of body weight on carcass traits, the average carcass weight was used as the concomitant variable in model II, and it was applied to calculate the carcass traits. A $P$-value $\leq 0.05$ was determined to be significant, and the Bonferroni test was performed for multiple comparisons of the genotypes.

Quantitative Real time PCR ( $q P C R$ ) verification

The relative expression levels of IncRNAs were detected using qPCR technology. The concentration and quality of all the RNA samples were assessed using the NanoDrop ND-1000 spectrophotometer (Thermo Scientific) and formaldehyde-agarose gel electrophoresis. The cDNA was synthesized using a cDNA Synthesis kit (Invitrogen) according to the manufacturer's instructions. In the experiment, $\beta$-actin was used as the housekeeping gene for the IncRNAs. ApoVLDL II as the estrogen response marker gene [45] was used as the positive control in the estradiol treatment experiments. The primers of all the genes of interest for qPCR were designed to span an exon- exon junction and are listed in Table 1. The relative expression levels of genes were quantified using the SYBR Green method with the Roche instrument Lightcycle ${ }^{\mathrm{R}} 96$. The final volume of each reaction was $10 \mu \mathrm{L}$, including $5 \mu \mathrm{L}$ of SYBR Green PCR Master Mix (Takara), $3.5 \mu \mathrm{L}$ of RNasefree water, $0.5 \mu \mathrm{L}$ each of the forward and reverse primers, and $0.5 \mu \mathrm{L}$ of cDNA template. The amplification process was as follows: $95^{\circ} \mathrm{C}$ for $3 \mathrm{~min}, 40 \mathrm{cycles}$ of $95^{\circ} \mathrm{C}$ for $12 \mathrm{sec}, 61^{\circ} \mathrm{C}$ for $40 \mathrm{sec}$, and $72^{\circ} \mathrm{C}$ for $30 \mathrm{sec}$, followed by an additional 10 -min extension at $72^{\circ} \mathrm{C}$. All reactions were run in three duplicates, and the relative gene expression levels were analyzed using the $2^{-\Delta \Delta c t}$ method [46].

\section{Statistical Analysis}

Results are presented as the means \pm standard deviations. Statistical analysis was performed by using the Student's t test, and a $P$-value $\leq 0.05$ was considered significant.

\section{Results}

\section{LncRNA identification}

The process applied to analyze the known and novel transcript lncRNAs is showed in Fig 1. A total of 6543 differentially expressed lncRNAs, including 5953 known and 590 novel lncRNAs, were obtained for the liver of peak-laying hens (S1 Table - for all supplemental material see www.karger.com/10.1159/000494785/). Compared with pre-laying hens, 124 IncRNAs with a $P$-value $\leq 0.05$ were identified, among which 44 were significantly differentially expressed (SDE) with an FDR $\leq 0.05$, including 30 known and 14 novel lncRNAs (32 upregulated and 12 downregulated). NONGGAT008948.2, NONGGAT006128.2 and NONGGAT004598.2 were not expressed in the liver of pre-laying chickens, and the predicted novel lncRNA TCONS_00086867 was not expressed in peak-laying hens (S2 Table). Among the annotated known SDE IncRNAs, 12 were annotated in the NONCODE database, and the 


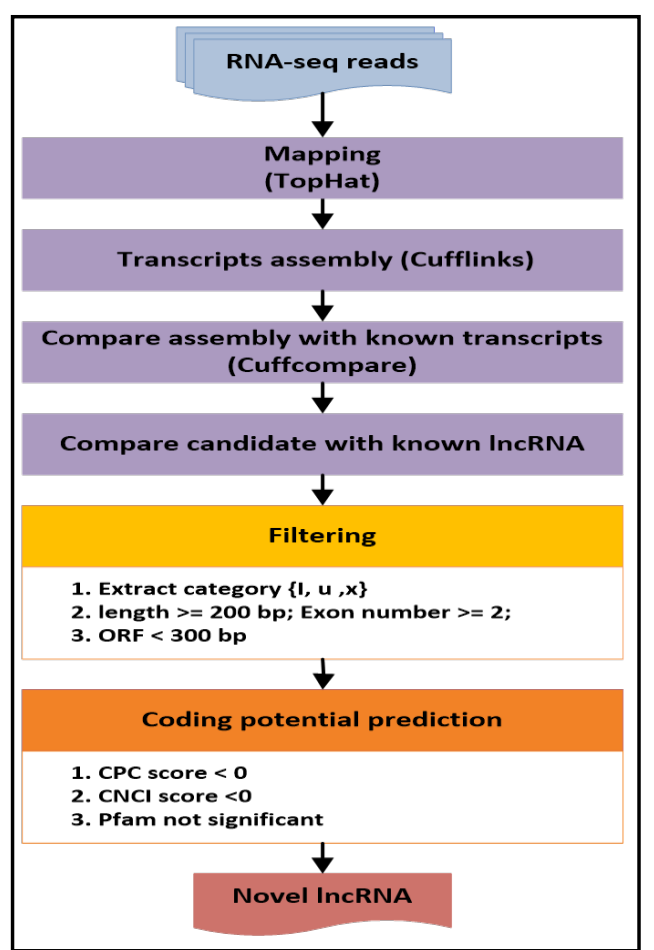

Fig. 1. Flow chart of known IncRNA identification and novel lncRNA prediction. I denotes a transfrag falling entirely within a reference intron; $u$ denotes the unknown, intergenic transcript; and $\mathrm{x}$ denotes exonic overlap with the reference on the opposite strand.

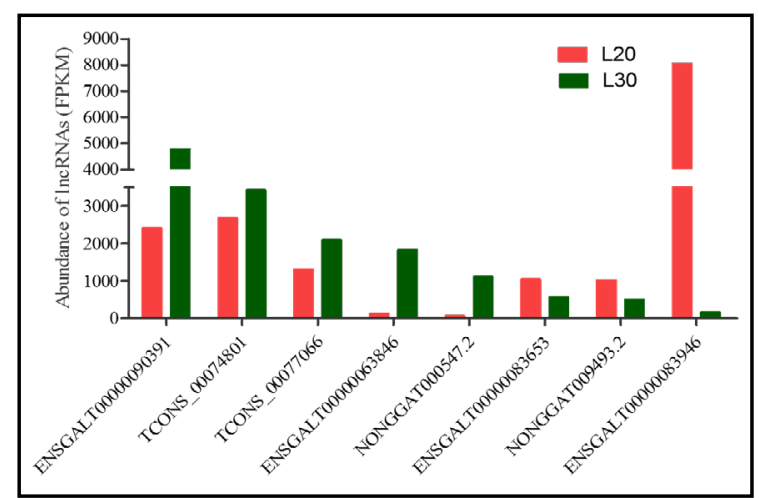

Fig. 2. The top ten most abundantly expressed IncRNAs in the liver of pre- and peak-laying chickens. All the lncRNAs were significantly expressed with an FDR $\leq$ 0.05 .

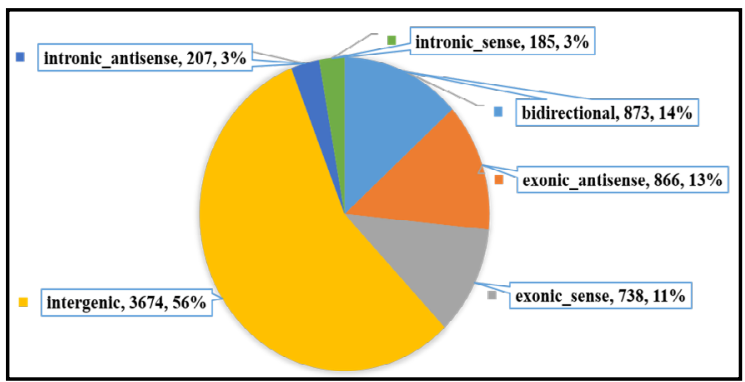

Fig. 3. The classification of lncRNAs expressed in the liver of chicken.

rest were annotated in Ensemble Release 89. The top ten most abundant lncRNAs expressed in peak-laying chicken liver were significantly differentially expressed (FDR $\leq 0.05$ ) (Fig 2). LncRNAs, including ENSGALT00000090391, TCONS_00074801, and TCONS_00077066, were highly expressed in both groups. The expression levels of ENSGALT00000063846 and NONGGAT000547.2 were increased 14- and 20-fold in the liver of peak-laying chickens, respectively. The significantly differentially expressed ENSGALT00000083946 with 50-fold downregulation had the highest abundance in the pre-laying stage. In addition, according to the various genomic positions of IncRNA types with respect to other genes, all the lncRNAs detected in both groups were classified into six types (S3 Table) as follows: intergenic, bidirectional, exonic_antisense, exonic_sense, intronic_sense and intronic_antisense. Of these, $56 \%(n=3674)$ were intergenic lncRNAs, followed by bidirectional (14\%), exonic _ antisense (13\%), and exonic_sense (11\%) (Fig 3).

\section{Characteristic comparison between IncRNAs and mRNAs}

To ensure that the predicted lncRNAs, including known and novel lncRNAs, fit the general characteristics, the transcript length, exon number and expression difference between IncRNAs and mRNAs were compared. As shown in Fig 4, the overall transcript length distribution of the lncRNAs (median 662 nucleotides) was shorter than the mRNAs (median 1, 558 nucleotides; $t$-test, $P$-value $\leq 1.0 \times 10^{-4}$ ), which was expected given the bias of lncRNAs having fewer exons and the relative lower expression abundance than the proteincoding genes. 
Fig. 4. LncRNA $\mathrm{t} r$ a $\mathrm{n}$ s c r i p t characterization. (A) Distribution of transcript lengths for IncRNAs (red) and protein-coding genes (green). (B) Distribution of the number of exons per transcript for IncRNAs (red) and p r o t e i n - c o d i n g genes (green). (C) Distribution of the transcript FPKM for IncRNAs (red) and protein-coding genes (green).

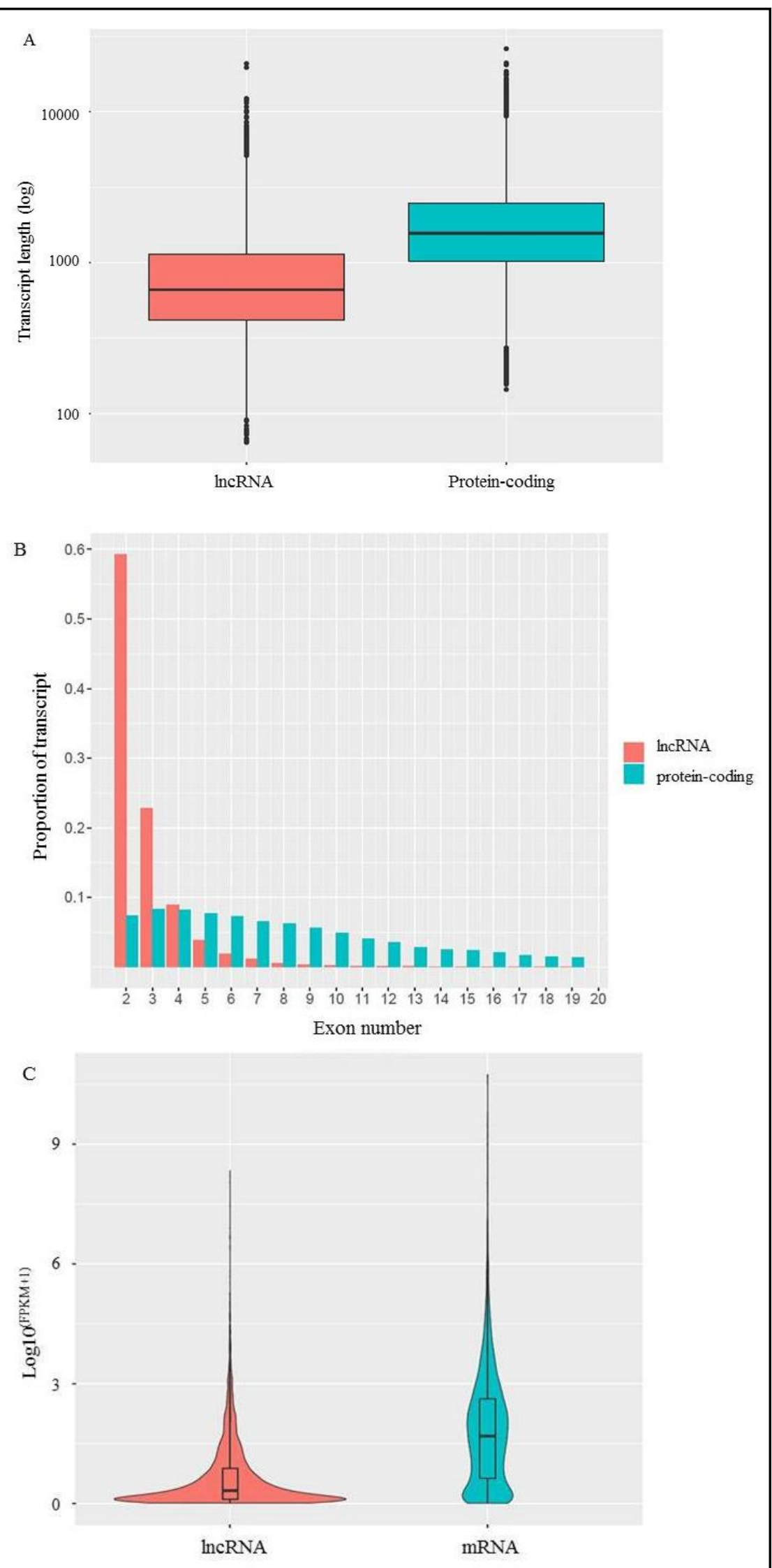


qPCR validation of
differentially expressed
IncRNAs

To estimate the reliability of the sequence data, seven DE IncRNAs $(P$-value $\leq 0.05)$, including six annotated and one novel lncRNA detected in the liver of pre- and egg-laying chickens were randomly selected for qPCR identification (Fig 5). Our data showed that expression patterns of IncRNAs NONGGAT003016.2, N O N G G A T 003795.2 , N O N G GAT 007149.2 , N O N G GAT 002911.2 , N O N G G A T 004633.2 , TCONS_00077066 and NONGGAT002034.2 obtained from RNA-seq were consisted with the validation results acquired via qPCR analysis. Our qPCR results suggested that the sequence result was reliable for further study.

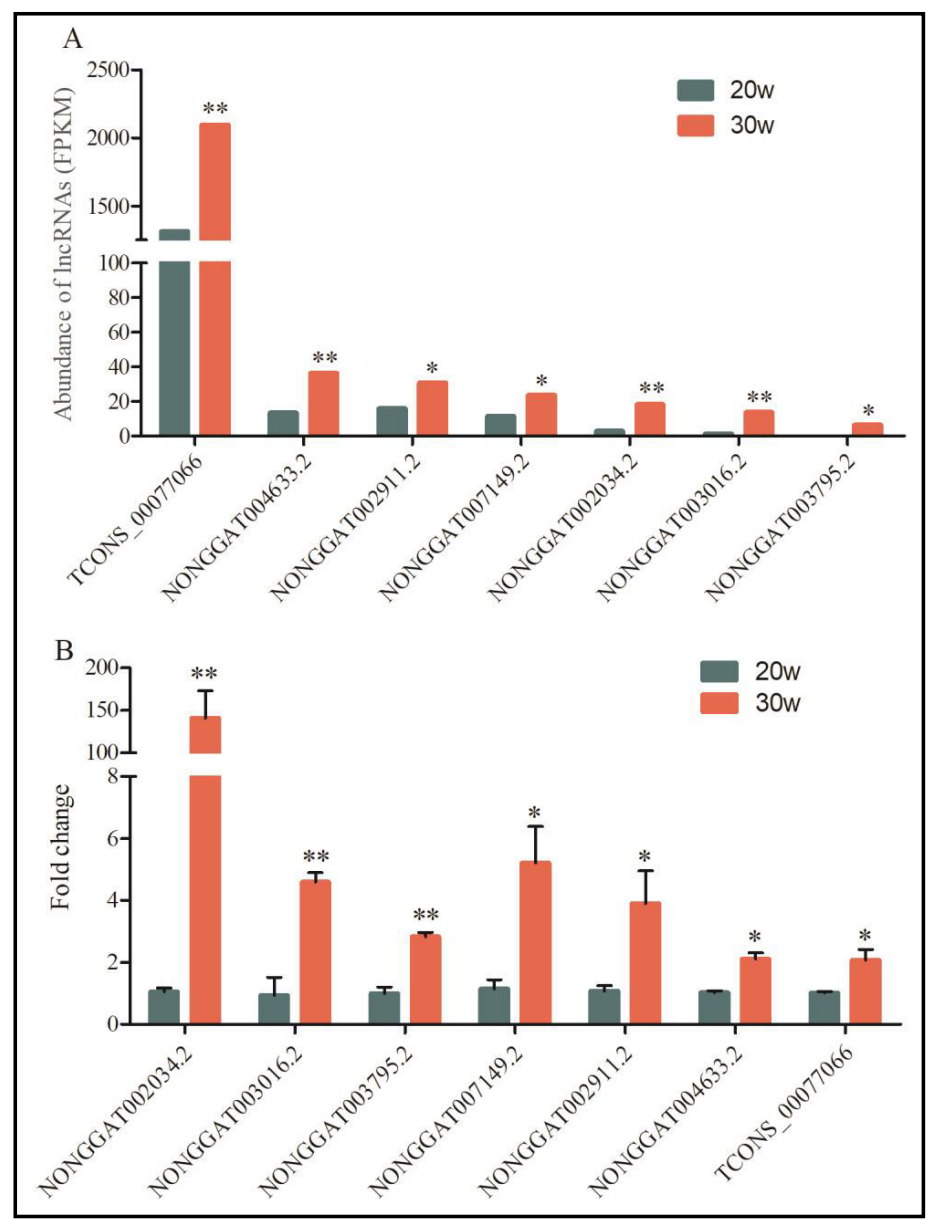

Fig. 5. The expression abundance and qPCR verification results of some differentially expressed lncRNAs in the liver of pre- and peaklaying chickens. A denotes the RNA-seq results; B denotes the qPCR results. *P-value $\leq 0.05 ; * *$ P-value $\leq 0.01$.

Table 2. The significantly enriched pathways of putative target genes of up- and down-regulated differentially expressed lncRNAs

\begin{tabular}{|c|c|c|c|c|c|c|}
\hline Category & ID & Term & P-Value & $\begin{array}{l}\text { Target } \\
\text { mRNA }\end{array}$ & $\begin{array}{c}\text { Acting } \\
\text { way }\end{array}$ & LncRNA \\
\hline \multirow[t]{12}{*}{$\begin{array}{l}\text { Up-regulated } \\
\text { lncRNAs }\end{array}$} & gga00400 & $\begin{array}{l}\text { Phenylalanine, tyrosine and } \\
\text { tryptophan biosynthesis }\end{array}$ & 0.0127 & GOT2 & Trans & ENSGALT00000088168 \\
\hline & \multirow[t]{5}{*}{ gga04080 } & Neuroactive ligand- & \multirow{5}{*}{0.0135} & & & ENSGALT00000075378 \\
\hline & & receptor interaction & & DRD3 & Trans & ENSGALT00000054392 \\
\hline & & & & PARD3 & Cis & NONGGAT003734.2 \\
\hline & & & & NTSR1 & Cis & NONGGAT003736.2 \\
\hline & & & & & & ENSGALT00000059156 \\
\hline & gga01210 & $\begin{array}{l}\text { 2-Oxocarboxylic acid } \\
\text { metabolism }\end{array}$ & 0.0272 & GOT2 & Trans & ENSGALT00000088168 \\
\hline & \multirow{2}{*}{$\begin{array}{l}\text { gga00360 } \\
\text { gga00120 }\end{array}$} & \multirow{2}{*}{$\begin{array}{c}\text { Phenylalanine metabolism } \\
\text { Primary bile acid } \\
\text { biosynthesis }\end{array}$} & 0.0293 & GOT2 & Trans & ENSGALT00000088168 \\
\hline & & & 0.0314 & $\mathrm{CH} 25 \mathrm{H}$ & Cis & NONGGAT008154.2 \\
\hline & gga00220 & Arginine biosynthesis & 0.0334 & GOT2 & Trans & ENSGALT00000088168 \\
\hline & gga00100 & Steroid biosynthesis & 0.0334 & DHCR24 & Trans & ENSGALT00000080371 \\
\hline & gga01040 & $\begin{array}{l}\text { Biosynthesis of unsaturated } \\
\text { fatty acids }\end{array}$ & 0.0396 & SCD & Cis & ENSGALT00000063846 \\
\hline \multirow{2}{*}{$\begin{array}{l}\text { Down- } \\
\text { regulated } \\
\text { lncRNAs }\end{array}$} & gga00590 & $\begin{array}{l}\text { Arachidonic acid } \\
\text { metabolism }\end{array}$ & 0.0114 & TBXAS1 & Cis & NONGGAT000448.2 \\
\hline & gga03018 & RNA degradation & 0.0198 & BTG2 & Cis & $\begin{array}{l}\text { NONGGAT005465.2 } \\
\text { NONGGAT005466.2 }\end{array}$ \\
\hline
\end{tabular}




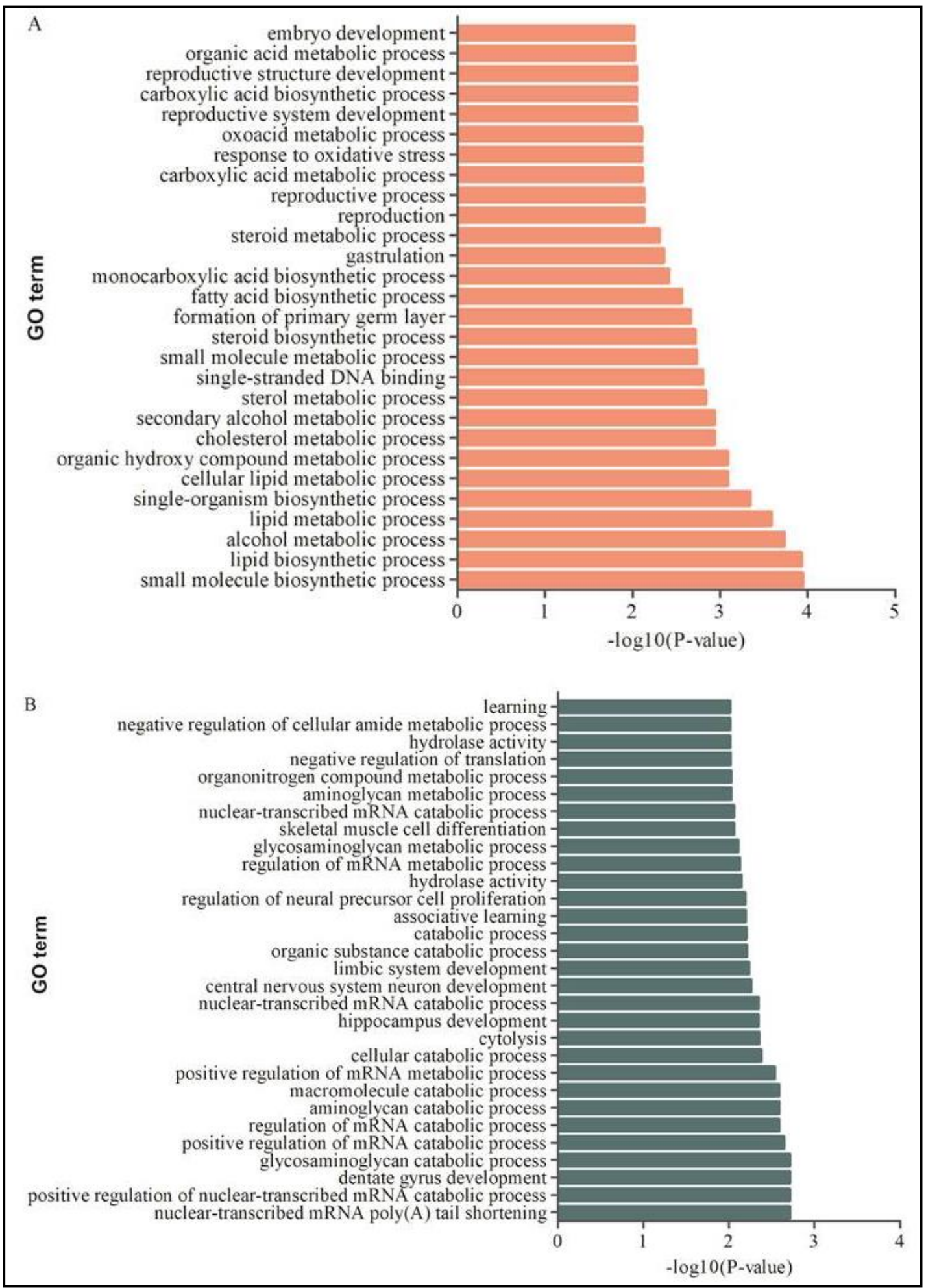

Fig. 6. The top enrichment GO terms for the target gene of up and downregulated differentially expressed lncRNAs in the liver of pre- and peak-laying chickens. Terms with P-value $\leq 0.01$ are shown. A denotes target gene-enriched GO terms for upregulated lncRNAs; B denotes target gene-enriched GO terms for downregulated lncRNAs. 


\section{Cellular Physiology Cell Physiol Biochem 2018;50:1638-1658 \begin{tabular}{ll|l} 
and Biochemistry Published online: 2 November 2018 & $\begin{array}{l}\text { (c) } 2018 \text { The Author(s). Published by S. Karger AG, Basel } \\
\text { www.karger.com/cpb }\end{array}$ \\
\hline
\end{tabular}

\section{Functional annotation of IncRNAs}

To correlate the differentially expressed IncRNAs with biological functions, we analyzed the functional bias of the 86 and 22 potential target genes for the 95 upregulated and 29 downregulated IncRNAs ( $P$-value $\leq 0.05$ ) according to the pathway analysis and GO enrichment, respectively (S4 Table).

The pathway analysis indicated that the target genes of the upregulated lncRNAs were significantly enriched in 8 pathways (Table 2). Most of the pathways were related to acid metabolism and biosynthesis, and some of those were related to lipid metabolism. The stearoyl-CoA desaturase (SCD) gene, as the potential target of ENSGALT00000063846, was enriched in the biosynthesis of unsaturated fatty acids pathway. The 24-dehydrocholesterol reductase (DHCR24), the putative target gene of both ENSGALT00000080371, was enriched in steroid biosynthesis. In addition, as the target of NONGGAT008154.2, cholesterol 25-hydroxylase $(\mathrm{CH} 25 \mathrm{H})$ was enriched in primary bile acid biosynthesis. The target genes of the downregulated IncRNAs were significantly enriched in two pathways, including arachidonic acid metabolism and RNA degradation.

GO annotation, an alternative approach for speculating about the possible function of a gene based on the GO numbers of target genes, was also performed to identify potential target genes of SDE IncRNAs. Our data showed that among the target genes upregulated by DE lncRNAs, the top four most significantly enriched GO terms were small molecule biosynthetic process, lipid biosynthetic process, alcohol metabolic process, and lipid metabolic process $(P$-value $\leq 0.01)$. Interestingly, most of the terms were correlated with lipid-related metabolic and biosynthetic processes (Fig 6A). To the target genes of the downregulated DE IncRNAs, the top four most significantly enriched GO terms were regulation of nuclear-transcribed mRNA catabolic process, nuclear-transcribed mRNA poly(A) tail shortening, positive regulation of nuclear-transcribed mRNA catabolic process, and dentate gyrus development $(P$-value $\leq 0.01)($ Fig 6B).

\section{Network regulation}

LncRNAs exert their biological functions by regulating target genes. Co-expression network analysis could predict the target genes of lncRNAs by analyzing their expression patterns. To address the relationship of how lncRNAs function in concert with their target mRNAs to participate in chicken hepatic metabolism and to identify critical regulators in the process, cis-and trans-targets of the SDE IncRNAs were predicted based on the DE expressed mRNA dataset obtained previously. Pearson's correlation coefficients of SDE lncRNAs and their DE target genes, equal to or greater than 0.98 and with a $P$-value $\leq 0.0001$, were used to draw the network using Cytoscape (S5 Table). A total of 184 mRNAs were identified to have common patterns with 29 lncRNAs. The co-expression network was composed of 393 connections and 213 network nodes. As the network indicated, one lncRNA could interact with dozens of mRNAs, and one mRNA could be correlated with many lncRNAs (Fig S1).

To identify putative miRNA-lncRNA interactions, miRNAs were gathered from miRbase 21. The miRNA target sites in the SDE lncRNAs were also predicted using Miranda and filtered by the DE miRNAs available from the GSE74242 dataset. The interaction network

Fig. 7. The expression of IncLTR in the liver of 20and 30-week-old chickens. (A) The high-throughput sequencing results for $\operatorname{lncLTR}$ in the liver of three 20- and 30-week-old chickens; (B) the qRT-PCR validation results for lncLTR expression in the liver of three 20- and 30-week-old hens. Different lowercase letters in each Fig. denote a significant difference (P-value $\leq 0.05$ ).

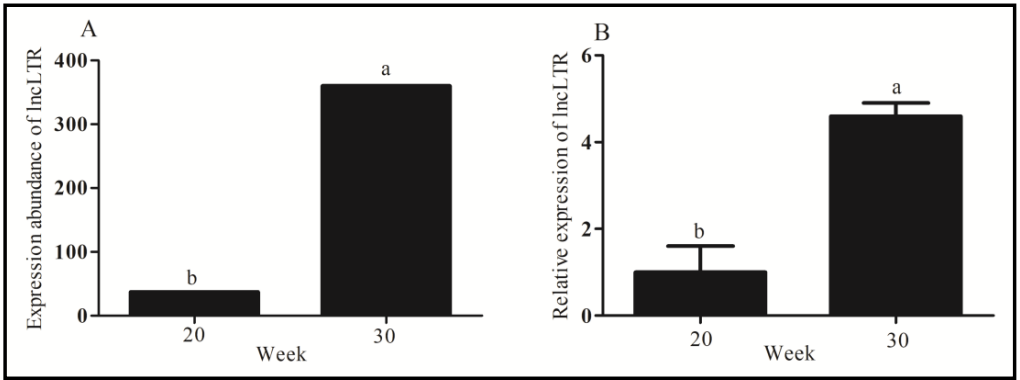


indicated that 11 SDE IncRNAs interacted with 14 DE miRNAs, including 25 network nodes and 18 connections (S6 Table, Fig S2). Our data also suggested that one lncRNA could be targeted by several miRNAs, and some lncRNAs shared the same target miRNA.

LncRNAs and miRNAs are endogenously expressed regulators of gene expression [47]. We analyzed possible interaction networks among lncRNAs, miRNAs and mRNAs in chicken liver. Based on the interaction between IncRNAs and miRNAs, the DE target genes of the DE miRNAs (S7 Table) were analyzed based on our previous work [36], and the network was constructed using Cytoscape. It was found that 14 miRNAs, 11 lncRNAs and 159 proteincoding genes were involved in the network (Fig S3).

\section{Characterization of the IncLTR sequence and expression pattern}

The expression of IncLTR was significantly increased in the liver of 30-week-old compared with 20-week-old chickens based on the sequence data. The qPCR validation showed that the IncLTR increased 4.5 -fold in the liver of peak-laying relative to pre-laying hens (Fig 7). Further analysis indicated that IncLTR was an intergenic long noncoding RNA with a known sequence size of $776 \mathrm{bp}$ localized in a region of chicken genome chromosome 16:261196-268788. Analysis using the commonly used algorithms indicated that the lncLTR lacked any coding capacity. In addition, none of the predicated short open reading frames (ORFs) in the lncLTR matched any known proteins or functional protein motifs in the current proteome databases.

\section{Tissue expression pattern}

To understand the expression characteristic of the IncLTR in the liver of egg-laying chickens at different physiological periods, time course expression analysis in liver tissue was conducted. The results revealed significantly different expression levels of the lncLTR gene at different development stages (Fig 8). Before the peaklaying stage, lncLTR expression levels were not

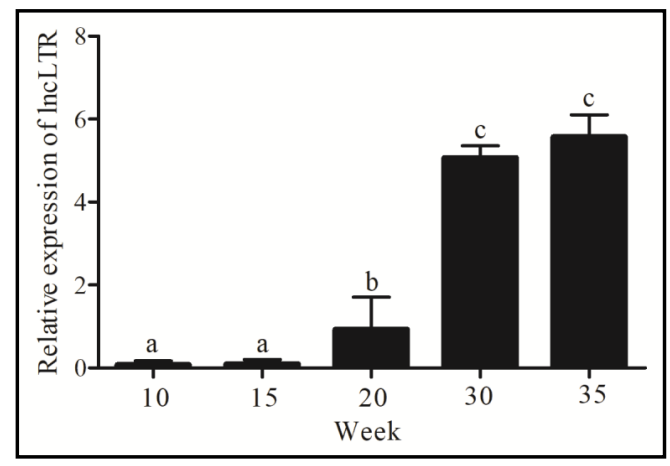

Fig. 8. The relative expression levels of IncLTR in the liver of chickens at different growth stages. Data are expressed as the means $\pm \operatorname{SD}(n=8)$.
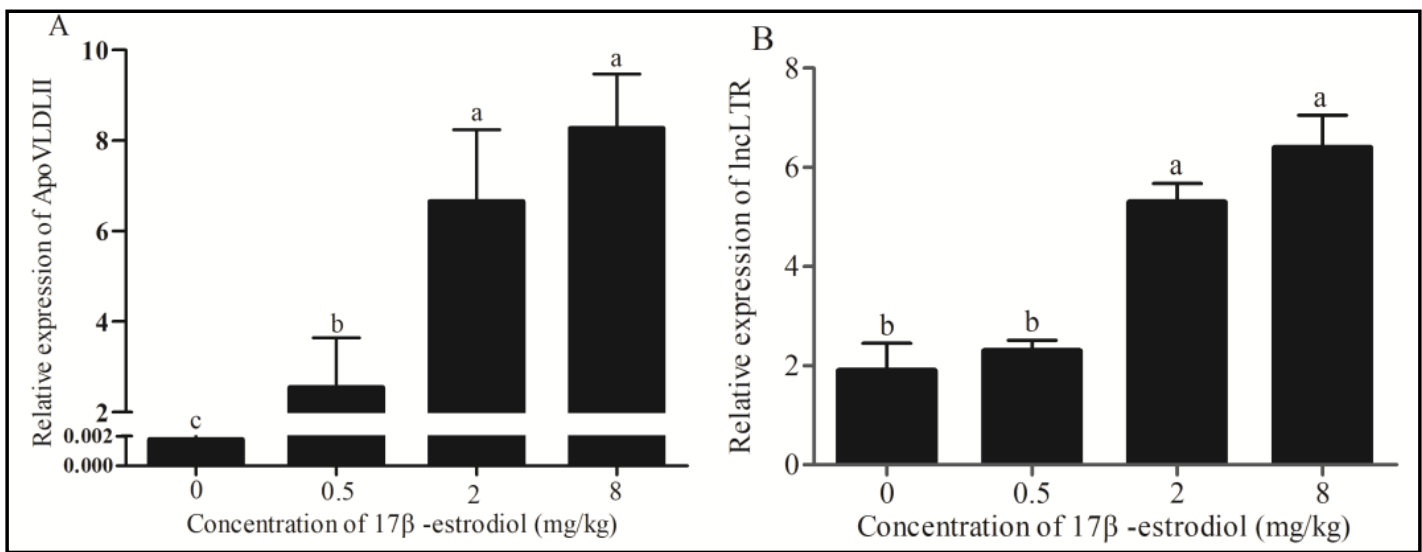

Fig. 9. The relative expression levels of IncLTR and ApoVLDL II in the liver of $17 \beta$-estradiol treated chicken. ApoVLDL II was used as a positive control in response to $17 \beta$-estradiol. (A) The effect of $17 \beta$-estradiol on the expression of ApoVLDL II in the liver of 10-week-old pullets after treatment for $12 \mathrm{~h}$. (B) The effect of $17 \beta$-estradiol on the expression of IncLTR in the liver of 10 -week-old pullets after treatment for $12 \mathrm{~h}$. Different letters in each Fig. indicate a significant difference among different $17 \beta$-estradiol concentrations (P-value $\leq 0.05)$. For each treatment, the data are expressed as the means \pm SD $(n=10)$. 
significantly different among 10-, 15- and 20-week-old chickens. However, expression levels of the IncRNA were significantly increased at the peak-laying period (30 and 35 weeks old) in comparison to the pre-laying stages $(P$-value $\leq 0.05)$.

\section{Effect of estrogen on IncLTR expression in vivo}

To detect whether the mRNA level of IncLTR in chicken liver was affected by estrogen, 10 -week-old hens were treated with different concentrations of $17 \beta$-estradiol $(0,0.5,2$, $8 \mathrm{mg} / \mathrm{kg}$ body weight). The expression of ApoVLDL II, an estrogen response marker gene, was quantified to estimate whether $17 \beta$-estradiol played a biological role after treatment. Our results showed that the expression of ApoVLDL II was significantly upregulated after the chickens were treated with different concentrations of $17 \beta$-estradiol $(P$-value $\leq 0.05)$. The mRNA expression level of lncLTR was also significantly increased when chickens were stimulated with $17 \beta$-estradiol at doses of $2 \mathrm{mg} / \mathrm{kg}$ and $8 \mathrm{mg} / \mathrm{kg}$ body weight $(P$-value $\leq 0.05)$ (Fig 9).

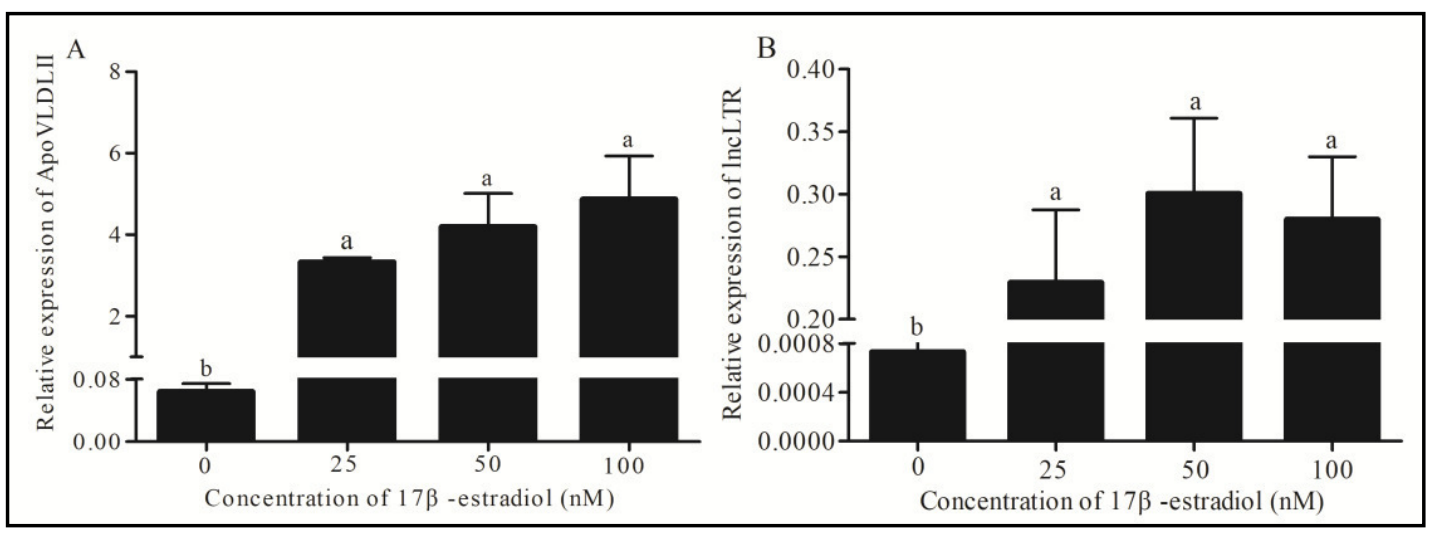

Fig. 10. The relative expression levels of IncLTR and ApoVLDL II in $17 \beta$-estradiol-treated chicken embryo hepatocytes. ApoVLDL II was used as a positive control in response to $17 \beta$-estradiol. (A) The effect of $17 \beta$-estradiol on the expression of ApoVLDL II in hepatocytes after treatment for $12 \mathrm{~h}$. (B) The effect of $17 \beta$-estradiol on the expression of IncLTR in hepatocytes after treatment for $12 \mathrm{~h}$. Different letters in each Fig. indicate a significant difference among different $17 \beta$-estradiol concentrations (P-value $\leq 0.05)$. For each treatment, the data are expressed as the means \pm SD $(n=6)$.

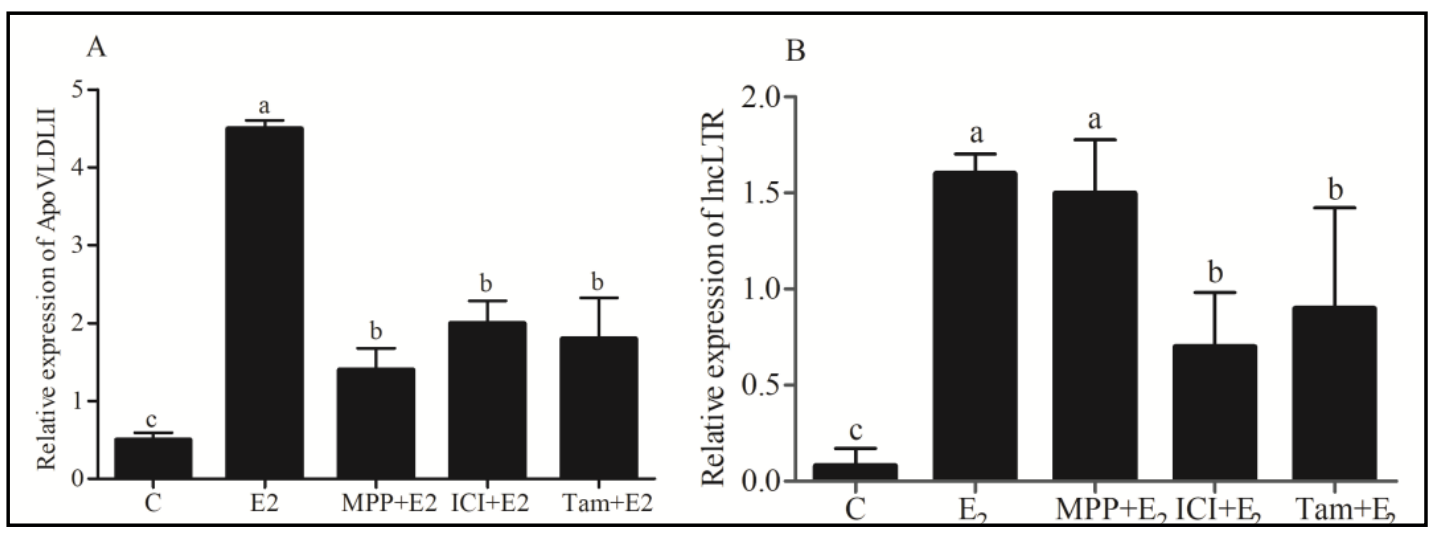

Fig. 11. Effects of ER antagonists on $17 \beta$-estradiol-induced expression of IncLTR and ApoVLDL-II in chicken embryo hepatocytes. E2:17 $\beta$-estradiol (100 nM); ICI: ICI 182,780 $(1 \mu \mathrm{M})$, TAX: tamoxifen $(1 \mu \mathrm{M})$, and MPP: (1,3-bis (4-hydroxyphenyl)-4-methyl-5-[4-(2-piperidinylethoxy) phenol]-1H-pyrazoledihydrochloride) (1 $\mu \mathrm{M})$. Different letters indicate significant difference among the different treatments (P-value $\leq 0.05)$. For each treatment, the data are expressed means $\pm S D(n=6)$. 


\section{Cellular Physiology Cell Physiol Biochem 2018;50:1638-1658 and Biochemistry \begin{tabular}{l|l} 
DOI: $10.1159 / 000494785$ & \\
(c) 2018 The Author(s). Published by S. Karger AG, Basel
\end{tabular}

Fig. 12. Validation of the different genotypes of the c242.G>A mutation by PCR product sequencing and RFLPPCR. (A) The genomic DNA sequence atlas of the GA heterozygous genotype. (B) Agarose gel electrophoresis (2.0\%) showing the SauI-RFLP fragments of the lncLTR gene PCR products. (C) The genomic DNA sequence atlas of GG wild genotype. (D) The genomic DNA sequence

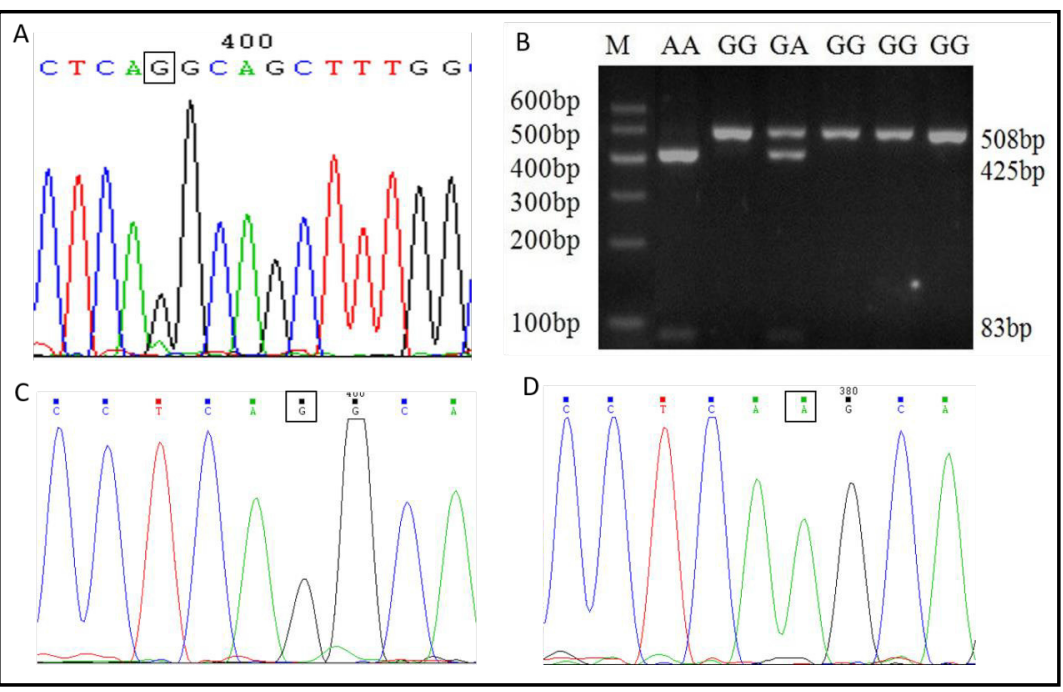
atlas of the AA mutation genotype. The 508-bp PCR products were digested into two fragments (425 and $83 \mathrm{bp}$ ) marked as the AA genotype, undigested (508 bp) fragments marked as the GG genotype, and three fragments $(508,425$, and $83 \mathrm{bp}$ ) marked as the GA genotype.

\section{Effect of estrogen on IncLTR expression} mediated by ER $\beta$

To further verify the effect of estrogen on the expression of lncLTR and to determine which estrogen receptor (ER) mediated the function of estrogen in the regulation of IncLTR expression, chicken hepatocytes were treated with different concentration of $17 \beta$-estradiol $(0,25,50$ and $100 \mathrm{nM}$ ) and different combinations of $17 \beta$-estradiol with 3 different estrogen receptor antagonists, respectively. MPP $(1,3$-bis (4-hydroxyphenyl)-4-methyl-
Table 3. Association analysis of different genotypes in lncLTR gene with chicken phenotypic traits. Note: BW12 = body weight at the age of 12-week-old; CW = carcass weight; EW = evisceration weight; SEW = semi-evisceration weight; $\mathrm{HW}=$ head weight; CLW = claw weight; DWW = double wings weight; $\mathrm{LDH}=$ lactic dehydrogenase; $\mathrm{CHE}=$ cholinesterase; $\mathrm{TG}=$ triglyceride. Means with different superscripts in the line means significant difference P-value $\leq 0.05$ among different genotypes; *means P-value $\leq 0.05$

\begin{tabular}{lccccc}
\hline \multicolumn{1}{c}{ Traits } & \multicolumn{4}{c}{ SNP genotype (mean \pm SE) } \\
& & GG & AA & GA & P-value \\
\hline Body weight & BW12(g) & $1348.07 \pm 20.66^{\mathrm{a}}$ & $1393.09 \pm 19.25^{\mathrm{a}}$ & $1328.43 \pm 15.91^{\mathrm{b}}$ & $0.011^{*}$ \\
Carcass Trait & CW(g) & $89.67 \pm 0.20$ & $90.18 \pm 0.18$ & $89.70 \pm 0.14$ & $0.043^{*}$ \\
& EW(g) & $916.63 \pm 15.31^{\text {ab }}$ & $951.45 \pm 14.24^{\text {a }}$ & $903.2 \pm 11.95^{\mathrm{b}}$ & $0.008^{*}$ \\
& SEW(g) & $1096.69 \pm 17.46^{\text {ab }} 1134.05 \pm 16.19^{\mathrm{a}}$ & $1083.47 \pm 13.56^{\mathrm{b}}$ & $0.018^{*}$ \\
& $\mathrm{HW}(\mathrm{g})$ & $43.07 \pm 0.53^{\mathrm{ab}}$ & $44.08 \pm 0.48^{\mathrm{a}}$ & $42.64 \pm 0.39^{\mathrm{b}}$ & $0.044^{*}$ \\
& $\mathrm{CLW}(\mathrm{g})$ & $58.69 \pm 1.08^{\mathrm{a}}$ & $58.69 \pm 1.08^{\mathrm{a}}$ & $57.46 \pm 0.82^{\mathrm{b}}$ & $0.040^{*}$ \\
& $\mathrm{DWW}(\mathrm{g})$ & $120.92 \pm 2.06^{\mathrm{b}}$ & $127.10 \pm 1.89^{\mathrm{a}}$ & $119.65 \pm 1.55^{\mathrm{b}}$ & $0.002^{*}$ \\
Blood biochemical index & $\mathrm{LDH}(\mathrm{U} / \mathrm{L})$ & $2786.19 \pm 51.38^{\mathrm{ab}} 2694.19 \pm 47.13^{\mathrm{b}}$ & $2832.16 \pm 39.65^{\mathrm{a}}$ & $0.033^{*}$ \\
& $\mathrm{CHE}(\mathrm{KU} / \mathrm{L})$ & $1.92 \pm 0.06^{\mathrm{ab}}$ & $1.85 \pm 0.06^{\mathrm{b}}$ & $1.99 \pm 0.05^{\mathrm{a}}$ & $0.045^{*}$ \\
& $\mathrm{TG}(\mathrm{mmol} / \mathrm{L})$ & $0.39 \pm 0.01^{\mathrm{b}}$ & $0.42 \pm 0.00^{\mathrm{ab}}$ & $0.43 \pm 0.01^{\mathrm{a}}$ & $0.007^{*}$ \\
\hline
\end{tabular}
5-[4-(2-piperidinylethoxy) phenol]-1H -pyrazoledihydrochloride) was used as the highly selective antagonist for ERalpha, ICI 182, 780 (Sigma-Aldrich) as the antagonist for both ER $\alpha$ and ER $\beta$, and tamoxifen (Sigma-Aldrich) as the antagonist for both ER $\alpha$ and ER $\beta$, although it may also act as an agonist of GPR30 on certain genes in some species [48, 49]. All antagonists were dissolved in DMSO. The results showed that the expression of ApoVLDL II was significantly upregulated after treatment with different concentrations of $17 \beta$-estradiol $(P$-value $\leq 0.05)$. Compared with the vehicle-treated controls, the mRNA level of IncLTR was significantly increased in the $17 \beta$-estradiol treated groups $(P$-value $\leq 0.05)$, but there were no significant differences among the different doses $(P$-value $>0.05)$ (Fig 10). In addition, in comparison to the control group, the upregulation effect of estrogen on IncLTR was not be inhibited by the specific antagonist of ER $\alpha$, MPP, but by the common antagonists of ER $\alpha$ and ER $\beta$ ICI 182, 780 and tamoxifen (Fig 11), suggesting that estrogen could induce the expression of lncLTR via ER $\beta$. 


\section{A SNP in IncLTR revealed potential function}

A single nucleotide polymorphism (SNP), c242.G > A, in lncLTR was detected via sequencing of the PCR product. The 508-bp PCR amplification products were digested with SauI restriction enzyme. Three genotypes, including AA (425 and 83 bp), AG (508, 425 and $83 \mathrm{bp}$ ) and GG (508 bp), were identified via PCR-RFLP analysis, and the wild and mutation homozygotic genotypes were confirmed by PCR sequencing in the F2 population generated by the Gushi×Anka chickens (Fig 12).

To investigate the functional effect of the $242 . \mathrm{G}>\mathrm{A}$ polymorphism in IncLTR on chicken phenotypic traits, least squares analysis between genotype of the $\mathrm{c} 242$. G $>$ A polymorphism in lncLTR and economic traits, including growth, meat quality, carcass weight, and blood biochemical parameter traits, were performed (S8 Table). The association results showed that the SNP was significantly associated to the 12 -week-old body weight trait $(P$-value $\leq$ $0.05)$, and the individuals with the AA genotype had a relatively higher body weight than those carrying GA at the age of 12 weeks, although the latter was relatively higher than the GG genotypes. The carcass traits were significantly associated with the SNP, and chickens with the AA genotype had heavier carcass weights, evisceration weights, semi-evisceration weights, head weights, double-wing weights, and claw weights than GA chicken $(P$-value $\leq$ $0.05)$, but the GA chickens were relatively heavier than the chickens with the GG genotype. A significant association was also found between the SNP and the blood biochemical parameters, including the serum lactic dehydrogenase, cholinesterase and triglyceride content $(P$-value $\leq 0.05)$, while the serum lactic dehydrogenase and cholinesterase content of chickens with the AA genotype were significantly higher than the GA $(P$-value $\leq 0.05)$ but not the GG genotype. Interestingly, the SNP was significantly associated with the serum triglyceride content, while GA chickens had significant higher levels than GG $(P$-value $\leq 0.05)$ but not AA chickens (Table 3). These results indicated that the SNP in IncLTR might influence triglyceride synthesis and chicken carcass traits.

\section{Discussion}

Understanding the function of IncRNA is critical to recognizing the contribution of these genes to biological processes involved in hepatic function. To the best of our knowledge, there are currently no reports in the literature examining the differentially expressed lncRNAs in egg-laying chicken hepatic tissues. The current study is for the first time to identify the expression profiles of hepatic lncRNAs in the livers of pre- and peak-laying chickens. Most importantly, many significant differentially expressed lncRNAs, including known and novel ones, were found in the liver of peak-laying compared with pre-laying chickens.

Because eggs are one of the richest sources of lipids [50], the physiological formation process of eggs is highly dependent on the metabolic function of the liver in chicken. The liver is a central metabolic organ, in which most of the de novo synthesis of fatty acid occurs in chicken $[51,52]$. The regulatory mechanisms underlying the protein-coding RNA involved in hepatic lipid metabolism have been extensively studied in chickens. Noncoding RNAs, including miRNAs and lncRNAs, have also been found to contribute to hepatic lipid metabolism in mammals. For example, miR-122 has been reported to be a key regulator of hepatic cholesterol and fatty acid metabolism in adult mice [53]. miR-33a/b contributes to the regulation of fatty acid metabolism in hepatic cell lines [54]. Some lncRNAs play key roles as regulators in hepatic metabolism. For example, LncLGRAs, the transcriptional regulatory factor of the hepatic GCK gene, can inhibit the expression of GCK and reduce hepatic glycogen content in mice during fasting [55]. Enhanced expression of IncRNA MALAT1 either in vivo or in vitro activates nuclear SREBP1c expression and induces its intracellular lipid accumulation in mouse hepatocytes [56]. Our previous studies have indicated that significant differentially expressed mRNAs and miRNAs in peak-laying chickens are highly relevant to hepatic lipid metabolism [27, 36]. However, the functions exerted by lncRNAs in the regulation of chicken hepatic lipid metabolism are largely unknown. Therefore, the underlying roles of 
SDE IncRNAs and the molecular regulatory network in this important physiological process remain to be elucidated.

Recently, a growing number of studies have demonstrated that lncRNAs are important factors in controlling mRNA expression [57], in cis (on neighboring genes) or in trans (distant genes). Predicting the function of lncRNA target genes can accelerate the study of lncRNAs. The results of bioinformatics analysis of the putative target genes of SDE IncRNAs showed that some target genes of IncRNAs were significantly enriched in diverse pathways. GO annotation showed that the target genes of upregulated lncRNAs were mainly enriched in lipid-related metabolic and biosynthetic processes, while they were enriched in various terms for the target genes of the downregulated lncRNAs. This finding might be explained by the observation that during the laying period, the lipid content and proportions of major lipid constituents were significantly increased in yolk [58, 59]. This result suggests that these differentially expressed IncRNAs may be associated with chicken hepatic lipid metabolism to some extent during the egg-laying stage.

A large number of studies have suggested that protein-coding mRNAs and lncRNAs can interact with each other and compete for miRNA binding [60]. The co-expression network analysis revealed a total of 393 connections and 213 network nodes between 184 coding genes and 29 lncRNAs. As the network indicated, one lncRNA could interact with dozens of mRNAs, and one mRNA could be correlated with several lncRNAs. It is reasonable to envision that some of these IncRNAs function as regulators of hepatic metabolism in chickens. Moreover, an ever-increasing number of studies have started to uncover the interaction among lncRNAs and miRNAs in mammals. In this study, integrated analyses of lncRNAmRNA, IncRNA-miRNA and IncRNA-miRNA-mRNA were conducted. We identified miR-22-3p as the most abundant SDE miRNA in chicken liver, playing a key role in the development of fatty liver in mice by steering the target genes and significantly increasing lipid accumulation in human hepatoma (HepG2) cells [61]. Our previous works have shown that miR-22-3p and miR-101-2-5p are involved in chicken hepatic lipid metabolic processes through targeting related genes [62,63]. As the potential target of miR-22-3p, IncRNA ENSGALT00000080371 might also be related to chicken hepatic lipid metabolism. In addition, NONGGAT000885.2 and NONGGAT002584.2 have been predicted to be targets of miR-146c-5p and miR-146a$5 p$, and both miR-146c-5p and miR-146a-5p have a relatively high abundance and are significantly downregulated in the liver of peak-laying chickens [36]. In addition to its relationship with human diseases, miR-146a-5p has been demonstrated to inhibit TNF$\alpha$-induced adipogenesis by targeting insulin receptor in primary porcine adipocytes [64], which may aid in understanding the possible function of lncRNAs. LncRNAs can be regulated by miRNAs that reduce their stabilities, and they can also function as molecular decoys or sponges of miRNAs [60].

Similar to miRNAs, many IncRNAs can also be induced by hormones [65], ligands [66], or lipoprotein [11], and these lncRNAs, especially the liver-enriched lncRNAs, can regulate lipid metabolism [67] despite having unclear functions. In our study, lncLTR expression was upregulated in chickens at the age of 20 weeks and was even more highly expressed at the age of 30 and $35 \mathrm{w}$. Many lncRNAs have been shown to be expressed in a cell-, tissue- and stage specific manner during development and differentiation $[68,69]$, suggesting that lncLTR may be involved in liver lipid metabolism or directly related to laying performance. As reported previously, the egg-laying process is highly dependent on the induction of estrogen [22], which led us to hypothesize that the SDE lncRNAs expressed in peak-laying chicken liver may also be affected by estrogen. The significant alteration of the ApoVLDL II mRNA level in the in vivo experiments indicated that $17 \beta$-estradiol played a biological role in chicken. The expression of IncLTR in liver tissue was significantly increased when chickens were stimulated with $17 \beta$-estradiol at doses of $2 \mathrm{mg} / \mathrm{kg}$ and $8 \mathrm{mg} / \mathrm{kg}$ body weight. This finding indicated that $17 \beta$-estradiol could induce the expression of IncLTR. Our in vitro experiments further confirmed that estrogen could promote the expression of lncLTR in chicken hepatocytes. Estrogen stimulates gene expression by binding to its receptors, including nuclear receptors (ER- $\alpha$ and ER- $\beta$ ) [70-73] and a membrane receptor (a G protein-coupled 


\section{Cellular Physiology Cell Physiol Biochem 2018;50:1638-1658 and Biochemistry \begin{tabular}{c|c|c|} 
DOl: 10.1159/000494785 \\
Published online:2 2 November 2018
\end{tabular} $\begin{aligned} & \text { O } 2018 \text { The Author(s). Published by S. Karger AG, Basel } \\
& \text { www.karger.com/cpb }\end{aligned}$ \\ Li et al.: Chicken LncRNA and Lipid Metabolism}

receptor, GPR30) [74]. Co-administration of 17 $\beta$-estradiol and ER-specific antagonists to primary chicken hepatocytes showed that MPP, the highly selective antagonist for ER- $\alpha$, did not suppress the expression of lncLTR. In contrast, IncLTR expression was significantly reduced by co-administration of $17 \beta$-estradiol with the antagonist ICI 182, 780 or tamoxifen in hepatocytes. These data suggested that ER- $\beta$ mediated the effect of estrogen during the induction of lncLTR expression in chicken liver. Moreover, some other SDE IncRNAs might also be controlled by estrogen, and further studies beyond the scope of this analysis will be conducted to test this hypothesis.

It is generally considered that the regulatory mechanism responsible for lncRNA expression is complex, and the biological roles of lncRNAs are difficult to confirm. The effects of SNPs on functional lncRNAs, however, are attracting more attention because of their potential influence on complex traits and diseases $[75,76]$. The results of our association analysis between the SNP and various traits showed that the c242.G>A SNP significantly influenced broiler growth traits at the later stage, as well as carcass traits. The A allele led to a heavier body weight and carcass traits than the $\mathrm{G}$ allele, presenting as a favorable mutation. Excitingly, the SNP was significantly associated with the blood biochemical parameter, including serum lactic dehydrogenase, cholinesterase, and especially triglyceride content. Triglycerides, as one of the main components of egg yolk precursors, is highly synthesized in the liver during the egg-laying period [23]. Thus, the SNP in IncLTR may influence triglyceride synthesis and chicken carcass traits. Given the results of the estrogen and SNP analysis trials, lncLTR is most likely involved in hepatic lipid metabolism in response to estrogen in chicken liver.

\section{Conclusion}

Our study describes, for the first time, the global expression profiling of lncRNAs in chicken liver. By conducting an integrated analysis of IncRNA-mRNA-miRNA, we found that many differentially expressed lncRNAs existed in chicken liver. Bioinformatics analysis helped to reveal possible associations between IncRNAs and coding genes to unravel potential functional roles of lncRNAs in the liver of egg-laying chickens. The integrated analysis among IncRNAs, mRNAs, and miRNAs enabled elucidation of the complex regulatory mechanism of chicken hepatic lipid metabolism. The expression of LncLTR was significantly higher in the liver of peak-laying than pre-laying hens. In vivo and in vitro experimental studies demonstrated that the expression of IncLTR was regulated by estrogen via ER $\beta$. The c242.G $>A$ SNP in IncLTR was related to triglyceride synthesis and chicken growth and carcass traits. Our data provide valuable information for explaining the mechanism responsible for lipid metabolism, and they lay the foundation for further studies on the molecular mechanisms of lncLTR action.

\section{Acknowledgements}

This research was supported by the Key Project of NSFC-Henan Province Joint Grand (NO. U1704233), the Open Projects of Key Laboratory of Chicken Genetics and Breeding, Ministry of Agriculture (NO. CGB-201701), the Production-Study-Research Cooperative Project, (N0.162107000066), and the Earmarked Fund for Modern Agro-Industry Technology Research System (No. CARS-41-K04).

HL performed the data analysis and drafted the manuscript. ZG and LY carried out the experiments and analyzed the data. YT and XK participated in the design of the experiments and the discussion. XL conceived the study, participated in the experimental design, and helped to draft the manuscript. All authors read and approved the final manuscript. 


\section{Cellular Physiology Cell Physiol Biochem 2018;50:1638-1658 and Biochemistry Published \begin{tabular}{l|l} 
DOI: $10.1159 / 000494785$ & $\begin{array}{l}\odot 2018 \text { The Author(s). Published by S. Karger AG, Basel } \\
\text { www.karger.com/cpb }\end{array}$
\end{tabular} \\ Li et al.: Chicken LncRNA and Lipid Metabolism}

The raw sequencing data, mapped data, and data for visualization of the RNA-Seq analyses of the chicken liver transcriptome data at different physiological stages have been deposited in the Gene Expression Omnibus (GEO) at the National Center for Biotechnology Information (NCBI) under accession number GSE70010.

\section{Disclosure Statement}

The authors declare that they have no competing interests.

\section{References}

1 Whitehead J, Pandey GK, Kanduri C: Regulation of the mammalian epigenome by long noncoding RNAs. BBA-Gen Subjects 2009;1790:936-947.

-2 Bernstein E, Allis CD: RNA meets chromatin. Gene Dev 2005;19:1635.

Wapinski O, Chang HY: Long noncoding RNAs and human disease. Trends Cell Biol 2011;21:354-361. Ponting CP, Oliver PL, Reik W: Evolution and functions of long noncoding RNAs. Cell 2009;136:629-641. Khalil AM, Guttman M, Huarte M, Garber M, Raj A, Morales DR, Thomas K, Presser A, Bernstein BE, Oudenaarden AV: Many human large intergenic noncoding RNAs associate with chromatin-modifying complexes and affect gene expression. P Natl Acad Sci USA 2009;106:11667-11672.

-6 Sun L, Goff LA, Trapnell C, Alexander R, Lo KA, Hacisuleyman E, Sauvageau M, Tazonvega B, Kelley DR, Hendrickson DG: Long noncoding RNAs regulate adipogenesis. P Natl Acad Sci USA 2013;110:3387-3392.

-7 Divoux A, Karastergiou K, Xie H, Guo W, Perera RJ, Fried SK, Smith SR: Identification of a novel IncRNA in gluteal adipose tissue and evidence for its positive effect on preadipocyte differentiation. Obesity 2014;22:1781-1785.

-8 Lv J, Huang Z, Liu H, Liu H, Cui W, Li B, He H, Guo J, Liu Q, Zhang Y: Identification and characterization of long intergenic non-coding RNAs related to mouse liver development. Mol Genet Genomics 2014;289:1225-1235.

9 Halley P, Kadakkuzha BM, Faghihi MA, Magistri M, Zeier Z, Khorkova O, Coito C, Hsiao J, Lawrence M, Wahlestedt C: Epigenetic Regulation of the apolipoprotein gene cluster by a long noncoding RNA. Cell Rep 2014;6:222-230.

10 Liu G, Zheng X, Xu Y, Lu J, Chen J, Huang X: Long non-coding RNAs expression profile in HepG2 cells reveals the potential role of long non-coding RNAs in the cholesterol metabolism. Chinese Med J-Pekin 2015;128:91-97.

-11 Hu YW, Yang JY, Ma X, Chen ZP, Hu YR, Zhao JY, Li SF, Qiu YR, Lu JB, Wang YC: A lincRNA-DYNLRB2-2/ GPR119/GLP-1R/ABCA1-dependent signal transduction pathway is essential for the regulation of cholesterol homeostasis. J Lipid Res 2014;55:681-697.

-12 Li P, Ruan X, Yang L, Kiesewetter K, Zhao Y, Luo H, Chen Y, Gucek M, Zhu J, Cao H: A liver-enriched long noncoding RNA, IncLSTR, regulates systemic lipid metabolism in mice. Cell Metab 2015;21:455-467.

-13 Cui M, Xiao Z, Wang Y, Zheng M, Song T, Cai X, Sun B, Ye L, Zhang X: Long non-coding RNA HULC modulates abnormal lipid metabolism in hepatoma cells through miRNA-9/PPARA/ACSL1/cholesterol/RXRA/HULC signaling. Cancer Res 2015;75:846-857.

-14 Ye S, Yang L, Zhao X, Song W, Wang W, Zheng S: Bioinformatics method to predict two regulation mechanism: TF-miRNA-mRNA and IncRNA-miRNA-mRNA in pancreatic cancer. Cell Biochem Biophys 2014;70:1849-1858.

15 Cesana M, Cacchiarelli D, Legnini I, Santini T, Sthandier O, Chinappi M, Tramontano A, Bozzoni I: A long noncoding RNA controls muscle differentiation by functioning as a competing endogenous RNA. Cell 2011;147:358-369.

16 Wang J, Liu X, Wu H, Ni P, Gu Z, Qiao Y, Chen N, Sun F, Fan Q: CREB up-regulates long non-coding RNA, HULC expression through interaction with microRNA-372 in liver cancer. Nucleic Acids Res 2010;38:5366-5383.

17 Bartel DP: MicroRNAs: Target Recognition and Regulatory Functions. Cell 2009;136:215-233.

18 Kaur P, Liu F, Tan JR, Lim KY, Sepramaniam S, Karolina DS, Armugam A, Jeyaseelan K: Non-Coding RNAs as potential neuroprotectants against ischemic brain injury. Brain Sci 2013;3:360-395. 


\section{Cellular Physiology Cell Physiol Biochem 2018;50:1638-1658 and Biochemistry DOI: 10.1159/000494785 2018 (0) 2018 The Author(s). Published by S. Karger AG, Basel

19 Li Z, Xiong C, Suo M, Tian H, Yu M, Mao T, Qian C, Luo H, Li Q Lu J: Comprehensive transcriptome analyses of the fructose-fed syrian golden hamster liver provides novel insights into lipid metabolism. Plos One 2016;11:e0162402.

-20 Muret K, Klopp C, Wucher V, Esquerré D, Legeai F, Lecerf F, Désert C, Boutin M, Jehl F, Acloque H: Long noncoding RNA repertoire in chicken liver and adipose tissue. Genet Sel Evol 2017;49:6.

-21 O’Hea EK, Leveille GA: Lipid biosynthesis and transport in the domestic chick (Gallus domesticus). Comp Biochem Phys 1969;30:149-159.

-22 Nikolay B, Plieschnig JA, Šubik D, Schneider JD, Schneider WJ, Hermann M: A novel estrogen-regulated avian apolipoprotein. Biochimie 2013;95:2445-2453.

23 Noble R: Comparative composition and utilisation of yolk lipid by embryonic birds and reptiles. in Deeming DC, Ferguson MWJ (eds): Egg incubation: Its effects on embryonic development in birds and reptiles. Cambridge, Cambridge University Press, 1991;17-28.

24 Muhammad A, Li X, Lundberg AE, Marcin K, Siegel PB, Örjan C, Stefan M: Identification of candidate genes and mutations in QTL regions for chicken growth using bioinformatic analysis of NGS and SNP-chip data. Front Genet 2013;4:226.

25 Gu X, Feng C, Ma L, Song C, Wang Y, Da Y, Li H, Chen K, Ye S, Ge C: Genome-wide association study of body weight in chicken F2 resource population. Plos One 2011;6:e21872.

26 Lv Z, Xu Q Yuan Y: A systematic review and meta-analysis of the association between long non-coding RNA polymorphisms and cancer risk. Mutat Res 2017;771:1-14.

27 Li H, Wang T, Xu C, Wang D, Ren J, Li Y, Tian Y, Wang Y, Jiao Y, Kang X: Transcriptome profile of liver at different physiological stages reveals potential mode for lipid metabolism in laying hens. BMC Genomics 2015;16:1-13.

28 Knauss JL, Sun T: Regulatory mechanisms of long noncoding RNAs in vertebrate central nervous system development and function. Neuroscience 2013;235:200-214.

29 Kong L, Zhang Y, Ye ZQ Liu XQ Zhao SQ, Wei L, Gao G: CPC: assess the protein-coding potential of transcripts using sequence features and support vector machine. Nucleic Acids Res 2007;35:W345.

30 Chen C, Deng B, Qiao M, Zheng R, Chai J, Ding Y, Peng J, Jiang S: Solexa sequencing identification of conserved and novel microRNAs in Backfat of large white and Chinese Meishan pigs. Plos One 2012;7:e31426.

31 Quinlan AR, Hall IM: BEDTools: a flexible suite of utilities for comparing genomic features. Bioinformatics 2010;26:841-842.

-32 Han L, Zhang K, Shi Z, Zhang J, Zhu J, Zhu S, Zhang A, Jia Z, Wang G, Yu S: LncRNA profile of glioblastoma reveals the potential role of IncRNAs in contributing to glioblastoma pathogenesis. Int J Oncol 2012;40:2004.

33 Xie C, Mao X, Huang J, Ding Y, Wu J, Dong S, Kong L, Gao G, Li CY, Wei L: KOBAS 2.0: a web server for annotation and identification of enriched pathways and diseases. Nucleic Acids Res 2011;39:316-322.

-34 Han W, Zou J, Wang K, Su Y, Zhu Y, Song C, Li G, Qu L, Zhang H, Liu H: High-throughput sequencing reveals hypothalamic MicroRNAs as novel partners involved in timing the rapid development of chicken (Gallus gallus) Gonads. Plos one 2015;10:e0129738.

35 Shannon P, Markiel A, Ozier O, Baliga NS, Wang JT, Ramage D, Amin N, Schwikowski B, Ideker T: Cytoscape: a software environment for integrated models of biomolecular interaction networks. Genome Res 2003;13:2498-2504.

-36 Li H, Ma Z, Jia L, Li Y, Xu C, Wang T, Han R, Jiang R, Li Z, Sun G: Systematic analysis of the regulatory functions of microRNAs in chicken hepatic lipid metabolism. Sci Rep 2016;6:31766.

37 Sun L, Luo H, Bu D, Zhao G, Yu K, Zhang C, Liu Y, Chen R, Zhao Y: Utilizing sequence intrinsic composition to classify protein-coding and long non-coding transcripts. Nucleic Acids Res 2013;41:e166.

38 Ren JX, XU NY, Ma Z, Li YM, Li CC, Wang YB, Tian YD, Liu XJ, Kang XT: Characteristics of expression and regulation of sirtuins in chicken (Gallus gallus). Genome 2016;60:431-440.

39 Fischer PWF, Marks GS: Chick embryo liver cells maintained in serum-free waymouth MD 705/1 medium. TCA Manual 1976;2:449-452.

40 Li H, Sun GR, Lv SJ, Wei Y, Han RL, Tian YD, Kang XT: Association study of polymorphisms inside the miR1657 seed region with chicken growth and meat traits. Brit Poultry Sci 2012;53:770.

41 Li H, Wang S, Yan F, Liu X, Jiang R, Han R, Li Z, Li G, Tian Y, Kang X: Effect of polymorphism within miRNA-1606 gene on growth and carcass traits in chicken. Gene 2015;566:8-12. 


\section{Cellular Physiology Cell Physiol Biochem 2018;50:1638-1658 and Biochemistry DOI: 10.1159/000494785 2018 (0) 2018 The Author(s). Published by S. Karger AG, Basel

42 Sambrook J, Russell DW: Molecular cloning: a laboratory manual, ed 3. Woodbury, Cold Spring Horbor Laboratory Press, 2001.

43 Han R, Li Z, Li M, Li J, Lan X, Sun G, Kang X, Chen H: Novel 9-bp indel in visfatin gene and its associations with chicken growth. Brit Poultry Sci 2011;52:52-57.

44 Han R, Wei Y, Kang X, Chen H, Sun G, Li G, Bai Y, Tian Y, Huang Y: Novel SNPs in the PRDM16 gene and their associations with performance traits in chickens. Mol Biol Rep 2012;39:3153-3160.

45 Mattsson A, Olsson JA, Brunström B: Activation of estrogen receptor alpha disrupts differentiation of the reproductive organs in chicken embryos. Gen Comp Endocr 2011;172:251.

-46 Schmittgen TD, Livak KJ: Analyzing real-time PCR data by the comparative CT method. Nat Protoc 2008;3:1101-1108.

47 Kaur P, Liu F, Tan JR, Lim KY, Sepramaniam S, Karolina DS, Armugam A, Jeyaseelan K: Non-coding RNAs as potential neuroprotectants against ischemic brain injury. Brain Sci 2013;3:360-395.

48 Thomas P, Pang Y, Filardo EJ, Dong J: Identity of an estrogen membrane receptor coupled to a G protein in human breast cancer cells. Endocrinology 2005;146:624.

49 Pang Y, Dong J, Thomas P: Estrogen signaling characteristics of Atlantic croaker G protein-coupled receptor 30 (GPR30) and evidence it is involved in maintenance of oocyte meiotic arrest. Endocrinology 2008;149:3410.

50 Weihrauch JL, Son Y-S: Phospholipid content of foods. J Am Oil Chem Soc 1983;60:1971-1978.

-51 O'hea E, Leveille G: Lipogenesis in isolated adipose tissue of the domestic chick (Gallus domesticus). Comp Biochem Phys 1968;26:111-120.

52 Leveille GA, O'Hea EK, Chakrabarty K: In vivo lipogenesis in the domestic chicken. Exp Biol Med 1968;128:398-401.

-53 Esau C, Davis S, Murray SF, Yu XX, Pandey SK, Pear M, Watts L, Booten SL, Graham M, McKay R: miR-122 regulation of lipid metabolism revealed by in vivo antisense targeting. Cell Metab 2006;3:87-98.

-54 Dávalos A, Goedeke L, Smibert P, Ramírez CM, Warrier NP, Andreo U, Cirera-Salinas D, Rayner K, Suresh U, Pastor-Pareja JC: miR-33a/b contribute to the regulation of fatty acid metabolism and insulin signaling. Natl Acad Sci USA 2011;108:9232-9237.

55 Ruan X, Li P, Cangelosi A, Yang L, Cao H: A Long Non-coding RNA, IncLGR, Regulates Hepatic Glucokinase Expression and Glycogen Storage during Fasting. Cell Rep 2016;14:1867-1875.

56 Yan C, Chen J, Chen N: Long noncoding RNA MALAT1 promotes hepatic steatosis and insulin resistance by increasing nuclear SREBP-1c protein stability. Sci Rep 2016;6:22640.

57 Ma H, Hao Y, Dong X, Gong Q, Chen J, Zhang J, Tian W: Molecular mechanisms and function prediction of long noncoding RNA. The Scientific World J 2012;2012:541786.

58 Fletcher D, Britton W, Rahn A, Savage S: The influence of layer flock age on egg component yields and solids content. Poultry Sci 1981;60:983-987.

59 Noble R, Lonsdale F, Connor K, Brown D: Changes in the lipid metabolism of the chick embryo with parental age. Poultry Sci 1986;65:409-416.

-60 Salmena L, Poliseno L, Tay Y, Kats L, Pandolfi PP: A ceRNA hypothesis: the Rosetta stone of a hidden RNA language? Cell 2011;146:353-358.

61 Kaur K, Pandey AK, Srivastava S, Srivastava AK, Datta M: Comprehensive miRNome and in silico analyses identify the Wnt signaling pathway to be altered in the diabetic liver. Mol BioSyst 2011;7:3234-3244.

62 Ma Z, Li H, Zheng H, Jiang K, Yan F, Tian Y, Kang X, Wang Y, Liu X: Hepatic ELOVL6 mRNA is regulated by the gga-miR-22-3p in egg-laying hen. Gene 2017;623:72-79.

63 Ma Z, Li H, Zheng H, Jiang KR, Jia LJ, Yan FB, Tian YD, Kang XT, Wang YB, Liu XJ: MicroRNA-101-2-5p targets the ApoB gene in liver of chicken (Gallus gallus). Genome 2017;60:673-678.

64 Wu D, Xi QY, Cheng X, Dong T, Zhu XT, Shu G, Wang LN, Jiang QY, Zhang YL: miR-146a-5p inhibits TNF$\alpha$-induced adipogenesis via targeting insulin receptor in primary porcine adipocytes. J Lipid Res 2016;57:1360-1372.

65 Yang L, Lin C, Jin C, Yang JC, Tanasa B, Li W, Merkurjev D, Ohgi KA, Meng D, Zhang J: LncRNA-dependent mechanisms of androgen receptor-regulated gene activation programs. Nature 2013;500:598.

66 Zhao XY, Li S, Wang GX, Yu Q Lin JD: A long noncoding rna transcriptional regulatory circuit drives thermogenic adipocyte differentiation. Mol Cell 2014;55:372-382.

67 Chen Z: Progress and prospects of long noncoding RNAs in lipid homeostasis. Mol Metab 2016;5:164-170. 


\section{Cellular Physiology Cell Physiol Biochem 2018;50:1638-1658

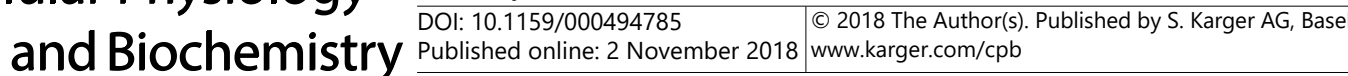

68 Dinger ME, Amaral PP, Mercer TR, Pang KC, Bruce SJ, Gardiner BB, Askarian-Amiri ME, Ru K, Soldà G, Simons C: Long noncoding RNAs in mouse embryonic stem cell pluripotency and differentiation. Genome Res 2008;18:1433-1445.

69 Pauli A, Valen E, Lin MF, Garber M, Vastenhouw NL, Levin JZ, Fan L, Sandelin A, Rinn JL, Regev A: Systematic identification of long noncoding RNAs expressed during zebrafish embryogenesis. Genome Res 2012;22:577-591.

-70 Hewitt SC, Korach KS: Oestrogen receptor knockout mice: roles for oestrogen receptors alpha and beta in reproductive tissues. Reproduction 2003;125:143.

71 Kuiper GG, Enmark E, Pelto-Huikko M, Nilsson S, Gustafsson JA: Cloning of a novel receptor expressed in rat prostate and ovary. Natl Acad Sci USA 1996;93:5925.

72 Jensen EV, Desombre ER: Estrogen-receptor interaction. Science 1973;182:126.

-73 Greene GL, Gilna P, Waterfield M, Baker A, Hort Y, Shine J: Sequence and expression of human estrogen receptor complementary DNA. Science 1986;231:1150-1154.

74 Makino A, Schmid-Schönbein GW: G-Protein coupled membrane receptors may serve as mechanosensors for fluid shear stress in neutrophils. Am J Physiol 2006;290:1633-1639.

75 Mei XX, Kang XT, Liu XJ, Jia LJ, Li H, Li ZJ, Jiang RR: Identification and SNP association analysis of a novel gene in chicken. Anim Genet 2016;47:125.

76 Wang JZ, Xiang JJ, Wu LG, Bai YS, Chen ZW, Yin XQ, Wang Q, Guo WH, Peng Y, Guo H: A genetic variant in long non-coding RNA MALAT1 associated with survival outcome among patients with advanced lung adenocarcinoma: a survival cohort analysis. BMC Cancer 2017;17:167. 